\title{
A Novel Small Molecule Supports the Survival of Cultured Dopamine Neurons and May Restore the Dopaminergic Innervation of the Brain in the MPTP Mouse Model of Parkinson's Disease
}

\author{
Ardashov, Oleg V.
}

$2019-10$

Ardashov , O V , Pavlova , A V , Mahato , A K, Sidorova , Y, Morozova , E A, Korchagina , D V , Salnikov , G E , Genaev , A M , Patrusheva, O S, Li-Zhulanov , N S , Tolstikova , T G , Volcho , K P \& Salakhutdinov , N F 2019 , ' A Novel Small Molecule Supports the Survival of Cultured Dopamine Neurons and May Restore the Dopaminergic Innervation of the Brain in the MPTP Mouse Model of Parkinson's Disease ' , ACS chemical neuroscience , vol. 10 , no. 10 , pp. 4337-4349 . https://doi.org/10.1021/acschemneuro.9b00396

http://hdl.handle.net/10138/322044

https://doi.org/10.1021/acschemneuro.9b00396

unspecified

acceptedVersion

Downloaded from Helda, University of Helsinki institutional repository.

This is an electronic reprint of the original article.

This reprint may differ from the original in pagination and typographic detail.

Please cite the original version. 


\section{Novel small molecule supports the survival of cultured dopamine neurons and restores dopamine innervation of the brain in the MPTP mouse model of Parkinson's disease}

Oleg V. Ardashov, ${ }^{\text {a,b }}$ Alla V. Pavlova, ${ }^{\text {a }}$ Arun Kumar Mahato, ${ }^{c}$ Yulia Sidorova, ${ }^{c}$ Ekaterina A.

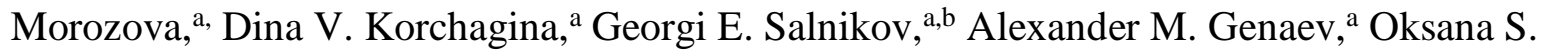
Patrusheva, ${ }^{\text {a }}$ Tat'yana G. Tolstikova, ${ }^{a}$ Konstantin P. Volcho*, ${ }^{a, b}$ Nariman Salakhutdinov ${ }^{\mathrm{a}, \mathrm{b}}$

${ }^{a}$ N. N. Vorozhtsov Novosibirsk Institute of Organic Chemistry, Siberian Branch, Russian Academy of Sciences, Lavrentiev ave., 9, 630090 Novosibirsk, Russian Federation

b Novosibirsk State University, Pirogova, 2, 630090 Novosibirsk, Russian Federation

c Laboratory of Molecular Neuroscience, Institute of Biotechnology, HiLIFe, Viikinkaari 5D, University of Helsinki 00014, Helsinki, Finland

\section{Abstract}

We previously showed that monoterpenoid (1R,2R,6S)-3-methyl-6-(prop-1-en-2yl)cyclohex-3-ene-1,2-diol 1 alleviates motor manifestations of Parkinson's disease in animal models. In the present study, we designed and synthesized monoepoxides of $(1 R, 2 R, 6 S)-3$-methyl-6(prop-1-en-2-yl)cyclohex-3-ene-1,2-diol 1 and evaluated their biological activity in the MPTP mouse model of Parkinson's disease. We also assessed the ability of these compounds to penetrate the blood brain barrier (BBB). According to these data, we choose epoxide 4, which potently restored locomotor activity in MPTP-treated mice and penetrated the BBB with high efficacy, to further explore the potential mechanism of action. Epoxide 4 was found to robustly promote the survival of cultured dopamine neurons, protect dopamine neurons from toxin-induced degeneration and trigger the mitogen-activated protein kinase (MAPK) signaling cascade in cells of neuronal 
origin. Meanwhile, neither survival-promoting effect nor MAPK activation was observed in nonneuronal cells treated with epoxide 4. In the MPTP mice model of Parkinson's disease, compound 4 increased the density of fibers expressing the key enzyme of dopamine synthesis, tyrosine hydroxylase. Taken together, these data indicate that epoxide 4 can be a promising compound for further development not only as symptomatic treatment but also as a disease-modifying drug to treat Parkinson's disease.

Keywords: Parkinson's disease, neurorestoration, MAPK signaling, ERK pathway, dopamine neurons, tyrosine hydroxylase.

\section{INTRODUCTION}

Parkinson's disease (PD) is the second most common neurodegenerative disorder worldwide. PD affects about $1-1.5 \%$ of the population over 60 years of age ${ }^{1}$; the lifetime risk of developing the disease is $1.5 \% .^{2}$ The economic burden of PD in the United States exceeded $\$ 14.4$ billion in $2010 .^{3}$ With the global phenomenon of population ageing, the number of PD cases is likely to grow significantly in the future. The major clinical diagnostic criteria for PD are tremor, rigidity, akinesia, postural instability, and bradyphrenia; depression is the most frequent psychopathological disorder. ${ }^{4}$ The diagnostic motor symptoms of PD are caused by progressive degeneration and death of dopamine neurons in the brain of affected people. ${ }^{5}$ There is no cure for PD. In other words, none of the existing medications can prevent, stop or slow down the underlying neuronal degeneration. Current management of PD is limited to supportive care that partially alleviates disease signs and symptoms. The dopamine precursor levodopa in combination with peripheral decarboxylase inhibitor is still the most available effective medication. The main adverse effects of levodopa therapy include nausea, motor complications, dyskinesias and on-off effects, confusion, 
hallucinations, orthostatic hypotension, and sleep disturbances. ${ }^{6-8}$ Importantly, levodopa only supplements endogenous dopamine but does not prevent progressive degeneration of dopamine neurons and may actually even promote it. ${ }^{9}$ Therefore, research into alternative strategies for PD treatment, especially the ones targeting neurodegeneration, is rather relevant today.

We have earlier ${ }^{10}$ discovered a small low-toxicity molecule $(1 R, 2 R, 6 S)$-3-methyl-6-(prop-1en-2-yl)cyclohex-3-ene-1,2-diol 1 (Fig. 1) that is able to potently alleviate motor symptoms in rodent models of PD. ${ }^{10-12} \mathrm{We}$ synthesized and tested in vivo a number of derivatives, including all eight stereoisomers of compound $\mathbf{1 .}{ }^{13}$ It was found that all of the four functional groups of $\mathbf{1}$ are needed for the compound to exhibit anti-PD activity. Among N-, O-, S- and C-derivatives at the C9 position of diol 1, compounds $\mathbf{2}$ and $\mathbf{3}$ with butyl or propylthio substituents exhibited a high activity. ${ }^{14}$

When exploring the chemical space around diol, we have synthesized all four isomeric monoepoxides 4-7 in the present study (Fig. 1) and investigated their ability to influence the locomotor activity in the MPTP-induced model of PD. The ability of selected epoxides to penetrate blood brain barrier was also evaluated. Since the mode of action and the molecular target(s) of diol and its derivatives still remained to be elucidated, we attempted to address this question. We also evaluated the ability of the most promising diol epoxide to promote the survival of dopamine neurons in vitro and in vivo in the MPTP-induced model of PD. 
<smiles>C=C(C)C1CC=C(C)C(O)[C@H]1O</smiles><smiles>C=C(CCCCC)C1CC=C(C)[C@H](O)[C@@H]1O</smiles><smiles>C=C(CSCCC)C1CC=C(C)C(O)[C@@H]1O</smiles>

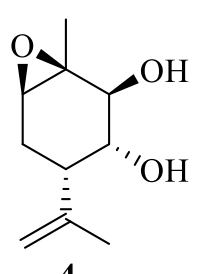

4

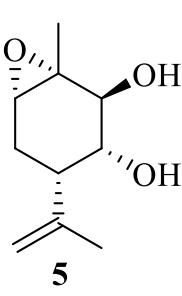

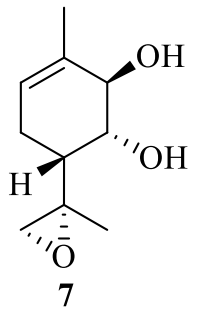

Figure 1. (1R,2R,6S)-3-Methyl-6-(prop-1-en-2-yl)cyclohex-3-ene-1,2-diol 1 and its derivatives 2-7

\section{RESULTS AND DISCUSSION}

\subsection{Synthesis of epoxides 4 and 5}

First, we focused on epoxidation of the 3,4 double bond in compound 1 . The attempts to epoxidize compound 1 with $t$ - $\mathrm{BuOOH}$ in the presence of $\mathrm{Ti}(i-\mathrm{PrO})_{4}$ (the Sharpless system $\left.{ }^{15}\right)$ or $\mathrm{VO}(\mathrm{acac})_{2}$ in accordance with the method described by Brown S. et al ${ }^{16}$ have failed: either the starting compound $\mathbf{1}$ has returned or a complex mixture of products was formed. The probable reason for that were secondary transformations of the epoxide group.

Next, we tried to use non-catalytic methods to oxidize compound 1 with $\mathrm{CH}_{3} \mathrm{CO}_{3} \mathrm{H} / \mathrm{NaHCO}_{3}$ or $m$-CPBA in $\mathrm{CH}_{2} \mathrm{Cl}_{2}$ (Scheme 1). Treatment with $\mathrm{CH}_{3} \mathrm{CO}_{3} \mathrm{H} / \mathrm{NaHCO}_{3}$ in $\mathrm{CH}_{2} \mathrm{Cl}_{2}$ at room temperature for $3 \mathrm{~h}$ gave rise to epoxides 4 and 5 with the yield of $16 \%$ and $4 \%$, respectively; conversion of diol 1 was $94 \%$. Oxidation of compound 1 with $m$-CPBA (1.45 eq.) in $\mathrm{CH}_{2} \mathrm{Cl}_{2}$ at $0{ }^{\circ} \mathrm{C}$ for one week led to formation of epoxides $\mathbf{4}$ and $\mathbf{5}$ with acceptable yields. The stereoisomeric epoxides 4 and $\mathbf{5}$ were isolated in their pure forms by column chromatography on silica; the yields of the products were $26 \%$ and $11 \%$, respectively; conversion of starting compound $\mathbf{1}$ was $91 \%$. In this case, we also detected $2 \%$ of epoxide 7 in the reaction mixture but failed to isolate it. Finally, 
when compound 1 was treated with $m$-CPBA (1.66 eq.) in $\mathrm{Et}_{2} \mathrm{O}$ for 3 weeks, the yields of products 4 and $\mathbf{5}$ were 32\% and 10\%, respectively; full conversion of diol $\mathbf{1}$ was achieved. Moreover, a mixture of four stereoisomeric diepoxides 8 was isolated with a $42 \%$ yield.

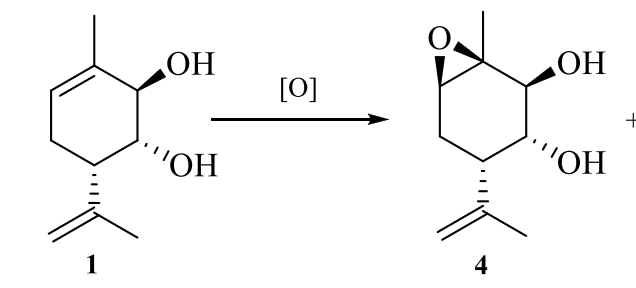

a) $\mathrm{CH}_{3} \mathrm{CO}_{3} \mathrm{H}, \mathrm{NaHCO}_{3}, \mathrm{CH}_{2} \mathrm{Cl}_{2}, 3 \mathrm{~h} \quad 16 \%$

b) $m$-CPBA (1.45 eq), $\mathrm{CH}_{2} \mathrm{Cl}_{2}, 1$ week $26 \%$

c) $m$-CPBA (1.66 eq), $\mathrm{Et}_{2} \mathrm{O}, 3$ week $\quad 32 \%$

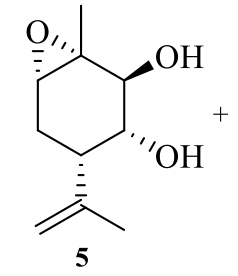

$4 \%$

$11 \%$

$10 \%$

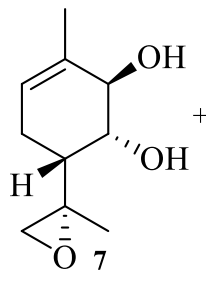

$(2 \%)$$$
\text { (2\%) }
$$

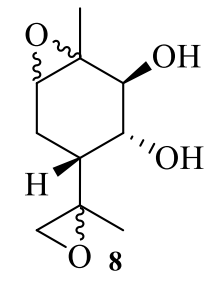

$42 \%$

Scheme 1. Epoxidation of compound 1.

\subsection{Synthesis of epoxides 6 and 7}

Since direct epoxidation of diol 1 proceeds predominantly at the endocyclic double bond, the iodohydrin approach was used to obtain stereoisomeric compounds $\mathbf{6}$ and 7. The interaction between diol 1 and iodine in the presence of water and $\mathrm{AcOH}$ in EtOAc led to $62 \%$ conversion of 1 within 5 days. $7 S$ - and $7 R$-epimeric iodohydrins $\mathbf{9}$ and $\mathbf{1 0}$ were obtained as products; the preparative yields calculated with respect to the consumed diol 1 were $29 \%$ and $11 \%$, respectively. Esterification proceeded as a side process and gave rise to monoacetates $\mathbf{1 1}$ and $\mathbf{1 2}$ with the yields of $12 \%$ and $4 \%$, respectively. In order to improve this yield, we conducted a similar reaction with diacetate $\mathbf{1 3}$, which was obtained from diol 1 with quantitative yield as described earlier by Ardashov O. et al. ${ }^{17}$ The interaction between diacetate $\mathbf{1 3}$ and iodine was much more selective than it was for diol $\mathbf{1}$ and predominantly gave rise to $7 S$-epimer 14 (43\% yield), whereas the content of minor $7 R$-stereoisomer 15 was only 6\%. Moreover, the products of partial hydrolysis $\mathbf{1 1}$ and $\mathbf{1 2}$ were isolated with the yields of $2 \%$ and $11 \%$, respectively (Scheme 2 ). 


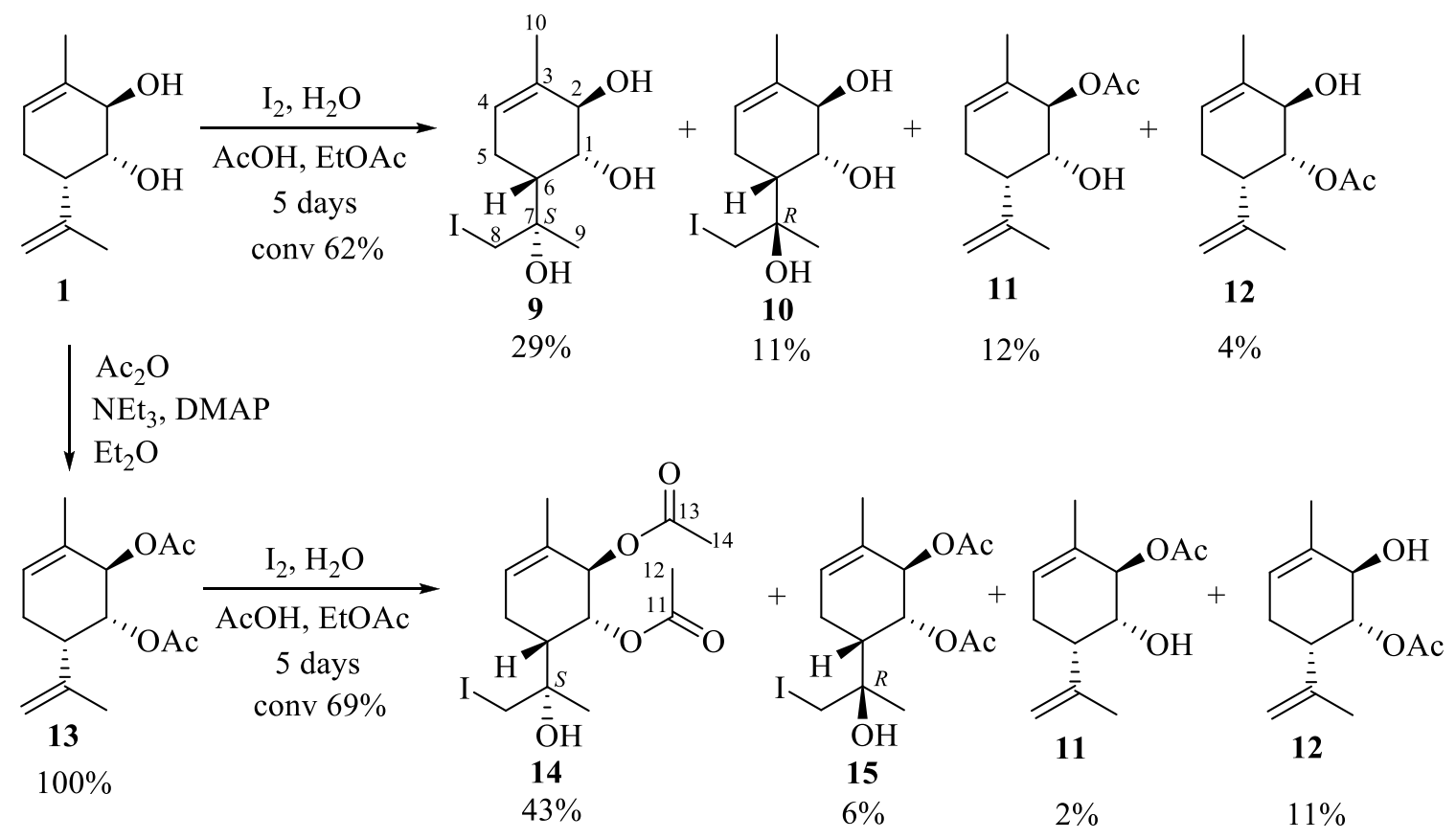

Scheme 2. Synthesis of iodohydrins.

Iodohydrin 10 was transformed to the respective epoxide $\mathbf{6}$ (88\% yield) using $i$ - $\operatorname{Pr}_{2} \mathrm{NEt}$ as a base in aqueous dioxane. A similar process for compound $\mathbf{1 4}$ included epoxide formation under the influence of $i$ - $\operatorname{Pr}_{2} \mathrm{NEt}$ and further saponification by $\mathrm{NaOH}$; it gave rise to epimeric epoxide 7 with a $84 \%$ yield (Scheme 3).

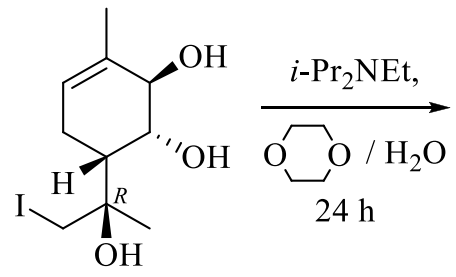

10<smiles>CC1=CC[C@@H](C(C)C)[C@H](O)[C@@H]1O</smiles>

6<smiles>CC(=O)O[C@H]1C(C)=CC[C@H](C(C)O)[C@H]1C(C)O</smiles>

14

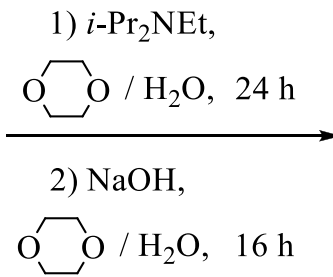

$\mathrm{O} \_\mathrm{O} / \mathrm{H}_{2} \mathrm{O}, 16 \mathrm{~h}$

$88 \%$

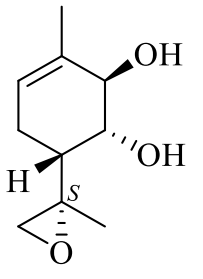

7 $84 \%$

Scheme 3. Synthesis of epoxides 6 and 7.

\subsection{Determination of the configuration of epoxide groups in compounds 4-7}

The configuration of epoxide groups in compounds $\mathbf{4}$ and $\mathbf{5}$ was determined using the ${ }^{1} \mathrm{H}$ NMR data by analyzing the vicinal ${ }^{1} \mathrm{H}-{ }^{1} \mathrm{H}$ constants of the $\mathrm{C}^{4} \mathrm{H}-\mathrm{C}^{5} \mathrm{H}_{2}-\mathrm{C}^{6} \mathrm{H}$ chain. 
Determining the configuration of epoxide groups in compounds $\mathbf{6}$ and 7 was a challenging task. Conformational analysis of epoxides 6 and 7 predicts that oxygen atom of the epoxide ring in the most energetically favorable forms of these epoxides is oriented towards the hydroxyl proton $\mathrm{OH}^{l}$ (Fig. 2). This specific conformation is fixed by a strong intramolecular hydrogen bond. The presence of this intramolecular $\mathrm{H}$-bond is confirmed by ${ }^{1} \mathrm{H}$ NMR: the $\mathrm{OH}^{1}$ signal lies downfield of the $\mathrm{OH}^{2}$ signal and has a much narrower lineshape. Due to the H-bond fixation of the epoxide conformation, the $R / S$-configuration of the $\mathrm{C}^{7}$ atom in both epoxides 6 and 7 can be reliably determined by NOESY. Indeed, strong cross-peaks are observed in the 2D NOESY spectrum of epoxide 6. These peaks correspond to NOE between the protons $\mathrm{H}^{1 e}$ and $\mathrm{H}^{8 e n}, \mathrm{H}^{5 e}$ and $\mathrm{CH}_{3}{ }^{9}, \mathrm{H}^{5 a}$ and $\mathrm{CH}_{3}{ }^{9}$, being indicative of the $R$-configuration of $\mathrm{C}^{7}$. On the contrary, NOE is observed between the protons $\mathrm{H}^{5 e}$ and $\mathrm{H}^{8 e n}, \mathrm{H}^{5 a}$ and $\mathrm{H}^{8 e n}, \mathrm{H}^{1 e}$ and $\mathrm{CH}_{3}{ }^{9}$ in the 2D NOESY spectrum of epoxide 7, corresponding to the $\mathrm{C}^{7} S$-configuration in 7 (Fig. 2).
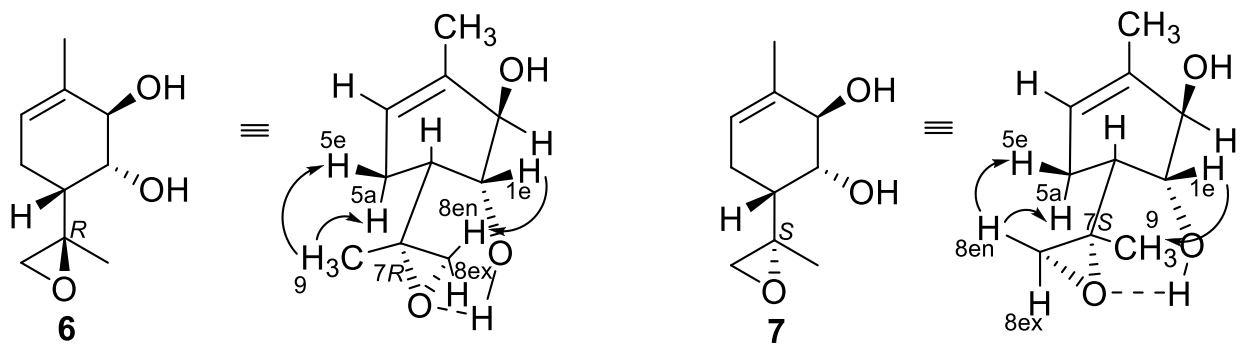

Figure 2. Configuration of epoxide groups in compounds $\mathbf{4}$ and $\mathbf{5}$.

Thus, all four isomeric epoxides 4-7 were successfully synthesized in pure form. Interestingly, when we compared mass-spectra and retention time in GC-MS for epoxides 4-7 with the data on metabolic profiling of diol 1 in vivo, we found out that epoxide $\mathbf{4}$ is a metabolite of diol 1 present in the blood of experimental animals. 
It is important that unlike epoxides 5-7 and other epoxides of similar structure, ${ }^{18,19}$ compound 4 is unusually stable in acidic conditions such as $10 \% \mathrm{H}_{2} \mathrm{SO}_{4}$ or montmorillonite clay K10.

\subsection{Studying the antiparkinsonian activity of epoxides 4-7}

We studied the biological activity of epoxide 4 (identified as a metabolite of compound 1) and isomeric compounds 5-7 in the MPTP mouse model of PD.

The MPTP-induced model is one of the most frequently used animal models of PD. ${ }^{5}$ In the brain, MPTP is converted to $\mathrm{MPP}^{+}$, which is selectively taken up by the dopamine transporter into dopaminergic neurons. ${ }^{20}$ In dopaminergic neurons, it blocks the electron transport chain in mitochondria and decreases the cellular ATP levels, which leads to formation of toxic reactive oxygen species and causes neuronal death. Systemic administration of MPTP causes reproducible lesions in the nigrostriatal dopaminergic pathway. Although this model has some limitations, MPTP is the only known dopaminergic neurotoxin capable of causing clinical presentation indistinguishable from idiopathic PD in humans. ${ }^{21}$

Parkinson's disease-like motor symptoms were induced in C57B1/6 mice by four injections of MPTP (0.12 mmol/kg (20 mg/kg) per dose, every $2 \mathrm{~h})$ in accordance with the procedure described earlier. ${ }^{21}$ The studied agents were administered per os $24 \mathrm{~h}$ after the last injection of MPTP at a dose of $20 \mathrm{mg} / \mathrm{kg}$. The main markers of locomotor activity were measured $2 \mathrm{~h}$ after administration of the agent using the open field test for 2 min. The effectiveness of the studied medication was evaluated according to its ability to reduce the symptoms of hypokinesia induced by MPTP.

Administration of MPTP to mice reduced their locomotor activity, in particular, in movement distance and duration of locomotor activity parameters (Fig. 3). 


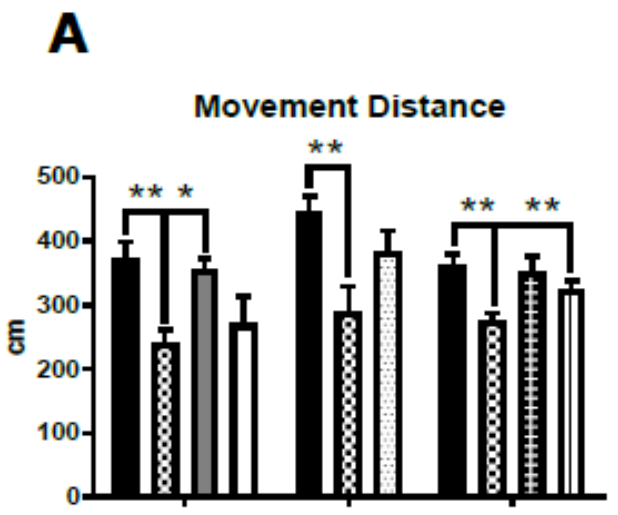

B

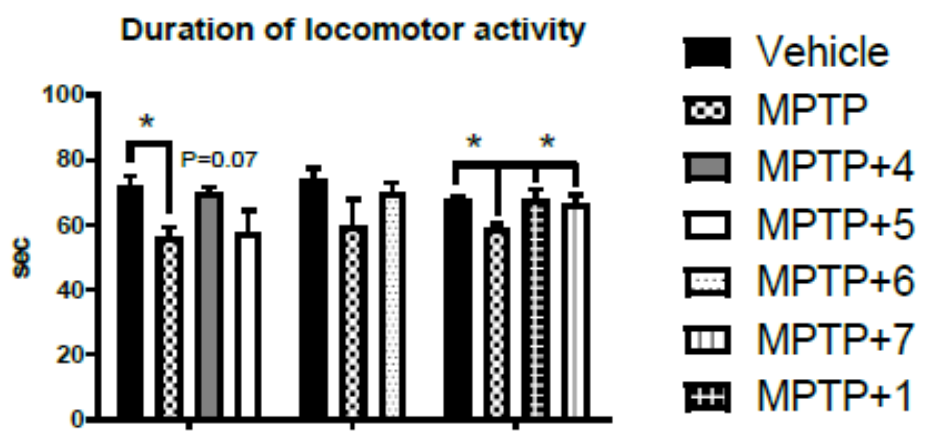

Figure 3. The influence of compounds 1, 4-7 $(0.12 \mathrm{mmol} / \mathrm{kg}(20 \mathrm{mg} / \mathrm{kg}))$ on locomotor activity of MPTP-treated $(4 \times 0.12 \mathrm{mmol} / \mathrm{kg}(4 \times 20 \mathrm{mg} / \mathrm{kg}))$ male C57B1/6 mice: movement distance $(\mathbf{A})$ and duration of locomotor activity (B). Mean \pm SEM. $\mathrm{N}=8-10$ mice per group. $* P<0.05, * * P<$ 0.01 compared to the MPTP group, ANOVA with Dunnett's post hoc test.

Administration of trans-epoxide 4 after MPTP neurotoxin injections led to a virtually complete recovery in movement distance and a trend towards increasing duration of locomotor activity in animals (Fig. 3, A and B). It should be noted that compound $\mathbf{4}$ given to naïve mice at the same dose had no effect on locomotor activity of the animals (Fig. 4).

Unlike trans-epoxide 4, cis-isomer 5 did not affect the locomotor activity in mice treated with MPTP (Fig. 3). Epoxide 6 also failed to influence locomotor activity. Meanwhile, isomeric epoxide 7 restored the locomotor activity of mice, which was previously reduced by MPTP. 

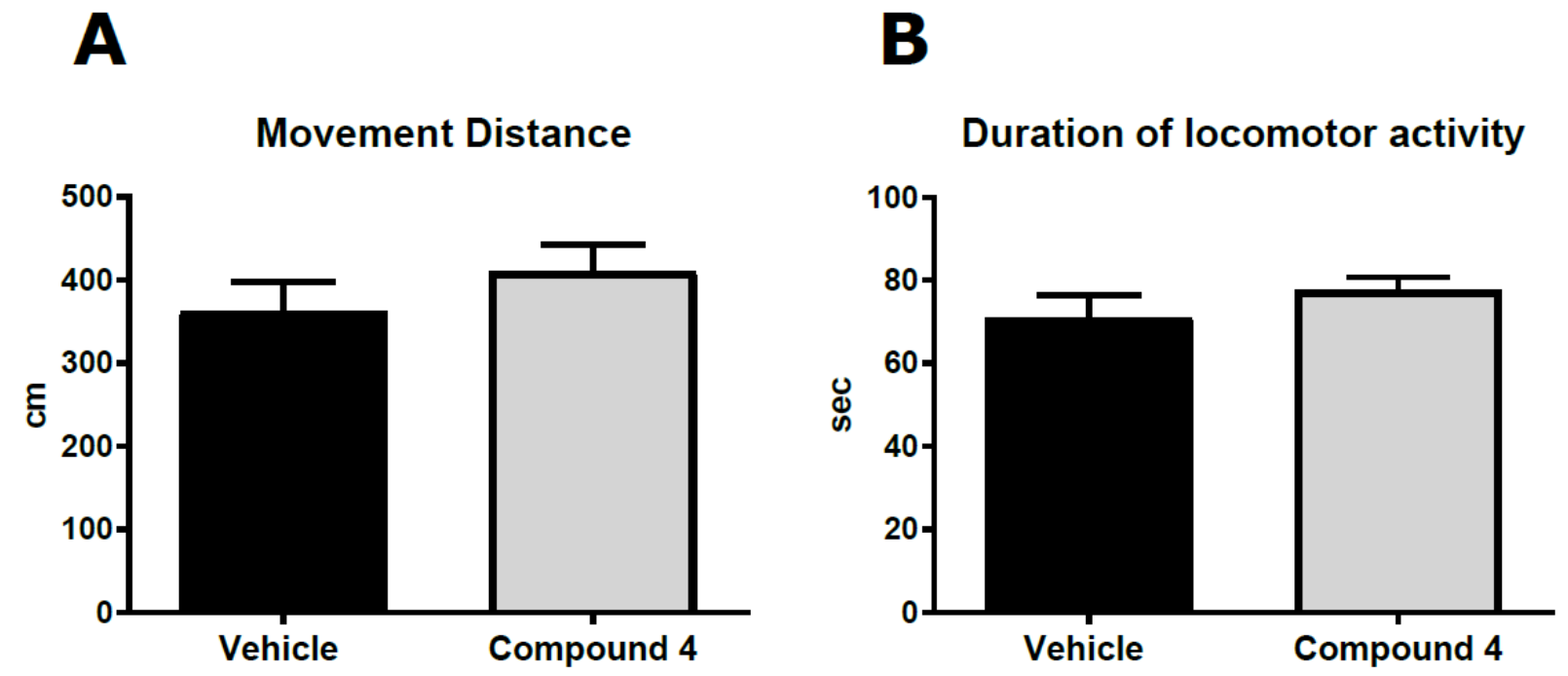

Figure 4. The influence of compound $4(0.12 \mathrm{mmol} / \mathrm{kg}(20 \mathrm{mg} / \mathrm{kg}))$ on locomotor activity of naïve male $\mathrm{C} 57 \mathrm{~B} 1 / 6$ mice. Mean $\pm \mathrm{SEM} . \mathrm{N}=10$ mice per group.

Thus, we found that two out of the four studied epoxides improved motor performance in the MPTP mouse model of PD. One of these compounds, epoxide 4, is the product of epoxidation of 3,4-double bound in compound $\mathbf{1}$, while another one, compound $\mathbf{7}$, is 7,8-epoxide of $\mathbf{1}$. It was demonstrated that configuration of epoxides played a decisive role in their ability to improve motor performance in the MPTP mouse model of PD.

Dose reduction of epoxide 4 to $5 \mathrm{mg} / \mathrm{kg}$ led to a less pronounced but statistically significant improvement of locomotor activity in MPTP-treated mice (Fig. 5). Unlike for the results obtained for compound 4 at a dose of $20 \mathrm{mg} / \mathrm{kg}$ (Fig. 3), restoration of locomotor activity (movement distance) was incomplete in this case. However, a statistically significant increase in duration of locomotor activity was observed. 


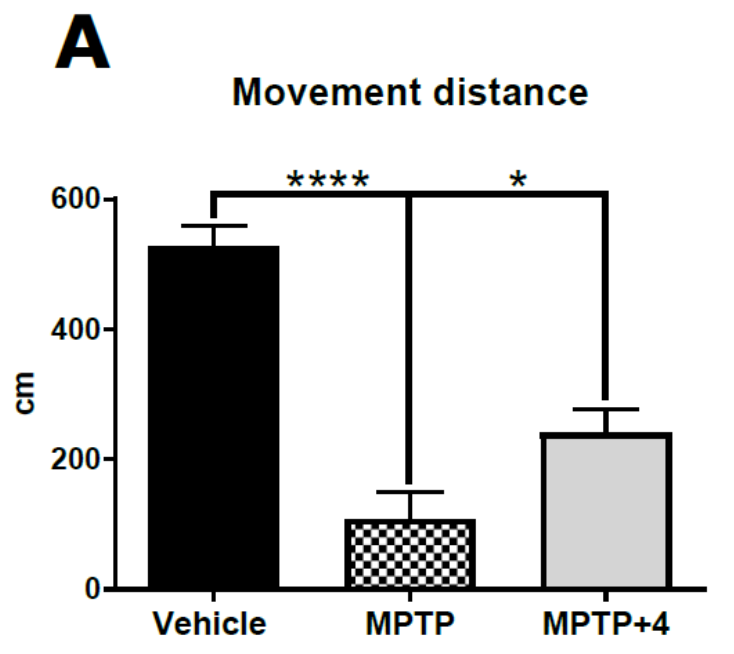

\section{B}
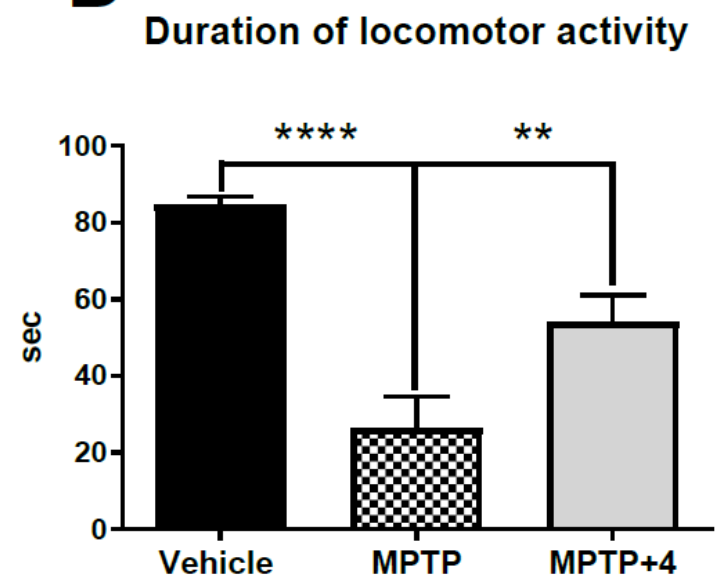

Figure 5. The influence of compound $4(0.03 \mathrm{mmol} / \mathrm{kg}(5 \mathrm{mg} / \mathrm{kg}))$ on locomotor activity of MPTPtreated $(4 \times 0.12 \mathrm{mmol} / \mathrm{kg}(4 \times 20 \mathrm{mg} / \mathrm{kg}))$ male C57Bl/6 mice. A - movement distance, $\mathbf{B}$ - duration of locomotor activity. Mean \pm SEM. $\mathrm{N}=10$ mice per group. $* P<0.05$, ** $P<0.01$, **** $P<$ 0.0001 compared to the MPTP group, ANOVA with Dunnett's post hoc test.

We studied the safety of active epoxides 4 and 7. No toxic and adverse effects were observed in response to a single oral $1000 \mathrm{mg} / \mathrm{kg}$ dose of these compounds. ${ }^{22}$ After 10 days, all animals were still alive and no abnormalities in general condition were found. Hence, these compounds exhibited low acute toxicity.

The ability of epoxide 4 to penetrate the blood-brain barrier was demonstrated by analyzing the brain and plasma extracts $1.5 \mathrm{~h}$ after oral administration of the epoxide 4 at a $10 \mathrm{mg} / \mathrm{kg}$ dose to rats. Compound 4 was found both in plasma $(5.3 \mu \mathrm{g} / \mathrm{mL})$ and in brain $(3.5 \mu \mathrm{g} / \mathrm{g})$. These data indicate that compound 4 readily penetrates the blood-brain barrier and remains in circulation for a relatively long time.

It is interesting to note that we also detected small amount of epoxide 4 in blood of experimental animals after administration of diol 1. These data indicate that epoxide 4 is a 
metabolite of compound 1. In the present study, we showed that it has biological activity in the MPTP mouse model of PD.

According to the results of biological experiments and taking into account the good chemical stability of epoxide $\mathbf{4}$, this epoxide was chosen for further studies.

\subsection{Insights into the molecular mechanism of action of compound 4}

Since the diagnostic symptoms of PD are caused by progressive degeneration of dopamine neurons, drugs protecting and/or restoring these neurons can significantly improve the management of PD. ${ }^{23-25}$ Therefore, we decided to test the ability of $0.01-10 \mu \mathrm{M}$ compound 4 to promote the survival of cultured embryonic dopamine neurons. Midbrain neurons were isolated from mouse embryos (E13.5) and cultured for five days in the presence of compound $\mathbf{4}$ or a vehicle. Dopamine neurons were labelled with antibodies specific to the key enzyme of dopamine synthesis, tyrosine hydroxylase (TH), imaged using CellInsight and counted using the Cell Profiler software. Glial cell line-derived neurotrophic factor (GDNF), the protein capable of supporting the survival of dopamine neurons, ${ }^{26,27}$ was used as a positive control. Compound 4 promoted the survival of naïve THpositive neurons in a dose-dependent manner. In the wells treated with $0.1 \mu \mathrm{M}$ and $1 \mu \mathrm{M}$ compound 4, the number of TH-positive neurons was $2.1(\mathrm{P}<0.05$, ANOVA with Dunnett's post hoc test) and $2.3(\mathrm{P}<0.01$, ANOVA with Dunnett's post hoc test) times higher, respectively, than in vehicletreated wells $(\mathrm{P}=0.028$, one-way ANOVA) (Fig. 6A).

We also studied the effect of compound $\mathbf{4}$ on the survival of TH-positive neurons in midbrain cultures treated with a toxin 6-hydroxydopamine (6-OHDA), a compound selectively killing dopamine neurons. ${ }^{23}$ Compound 4 protected cultured dopamine neurons from 6-OHDA-induced degeneration (Fig. 6B). 
Midbrain cell cultures contain other neuronal types in addition to dopamine neurons, in particular, significant proportion of neurons producing neurotransmitter gamma-aminobutyric acid (GABA). ${ }^{28}$ Therefore, we investigated the effect of compound 4 on the survival of these neurons. GABA-positive neurons were detected immuocytochemically with antibodies against GABA. We found that compound 4 failed to influence the survival of GABA neurons (Fig. 6C). Compound 4 was also unable to promote the proliferation of primary mesencephalic embryonic fibroblasts (Fig. 6D). These data indicate that the survival-promoting properties of epoxide 4 are restricted to the cells of neuronal origin and especially to dopamine neurons.

We further attempted to address the possible mechanisms of neuroprotective effect of epoxide 4 observed in dopamine neurons. It is known that the survival of cultured dopamine neurons can be positively affected by neurotrophic factors $\mathrm{GDNF}^{27}$ and brain-derived neurotrophic factor (BDNF). ${ }^{29}$ Hence, we accessed the ability of epoxide 4 to activate the receptors of these neurotrophic factors: receptor tyrosine kinases $\mathrm{RET}^{30}$ and $\operatorname{TrkB},{ }^{31}$ respectively. However, epoxide 4 activated neither RET (Fig. 6E), nor TrkB (Fig. 6F) in cultured murine fibroblasts MG87 overexpressing these receptors. In line with these data, epoxide $\mathbf{4}$ failed to activate Akt and mitogene-activated protein kinase (MAPK/ERK) downstream signaling cascades that are known ${ }^{32}$ to be important for the survival and functioning of mammalian cells in MG87RET fibroblasts (Fig. 6G). According to these results, we concluded that the neuroprotective effect of epoxide 4 can be mediated by a receptor or receptors expressed in neuronal cells other than RET or TrkB. Therefore, we assessed the ability of compound $\mathbf{4}$ to activate the MAPK and AKT signaling cascades in immortalized cells of neuronal origin. Indeed, the level of phosphorylated ERK in Neuro2A neuroblastoma cells increased (Fig 6H, the time point "15 minutes"). Quantification of the Western blotting images followed by statistical analysis of the data revealed that the average level of pERK in the cells treated with compound 4 was $32 \%$ higher than that in control $(\mathrm{P}<0.05$, paired t-test), 
whereas no changes were observed in the level of pAKT (Fig. 6I and 6J). The levels of pERK and pAKT normalized to GAPDH were calculated separately for each experimental time point and averaged afterwards, because the peaks of pERK and pAKT activation varied in time between the experiments, making direct comparison complicated.

Taken together, our results suggest that compound $\mathbf{4}$ may be promising both for treatment of disease progression in PD and for alleviation of PD symptoms. The receptor of compound 4 is yet to be determined. Furthermore, we cannot rule out the possibility that epoxide 4 has no its own neuroprotective properties; instead, it might influence the secretion of various neurotrophic factors supporting the survival of dopamine neurons as it has been shown for selegiline. ${ }^{33,34}$ 


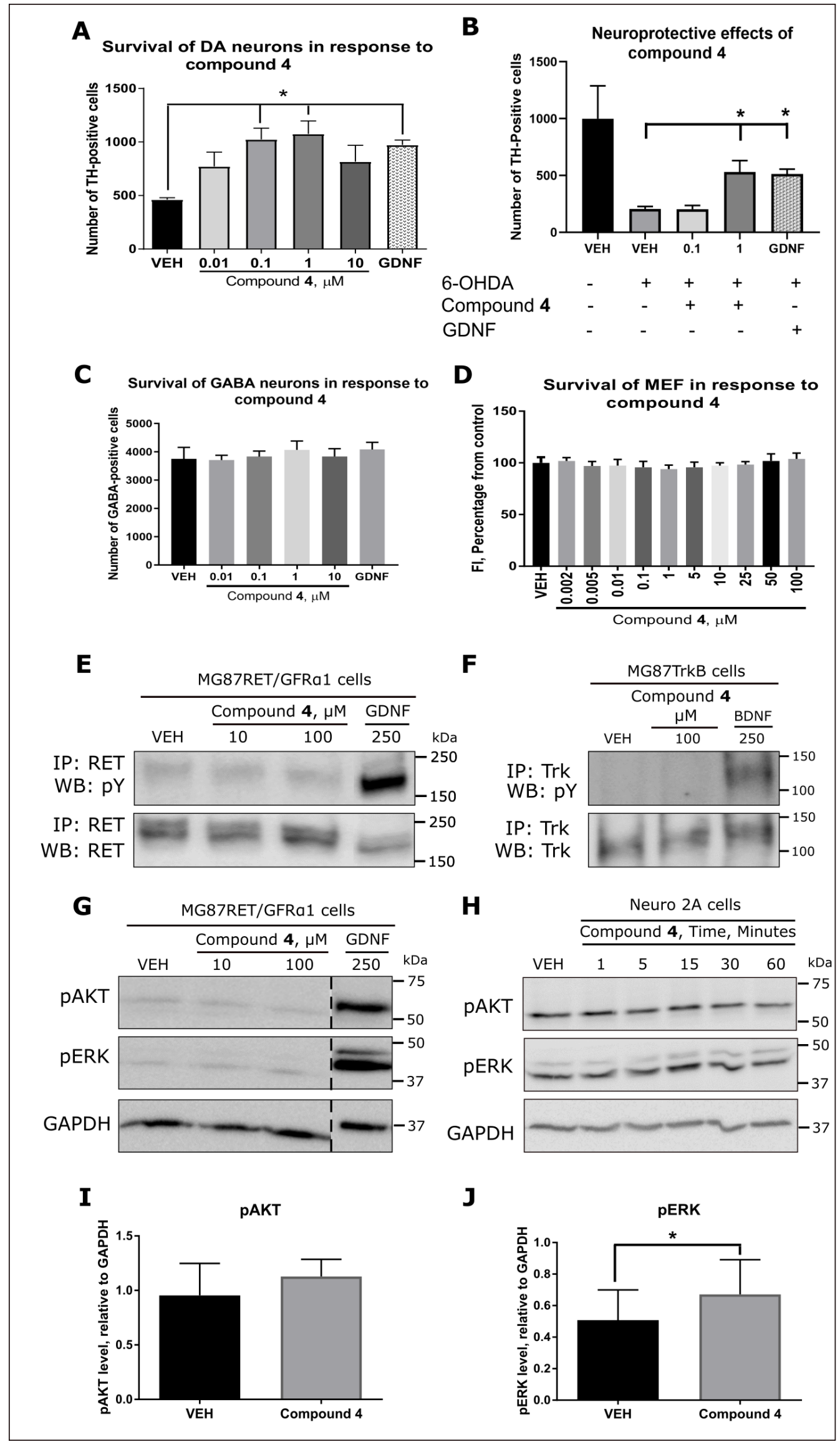


Figure 6. Biological effects of compound 4 in cultured cells. The influence of compound 4 on the survival of cultured naïve dopamine neurons (A), on the cultured dopamine neurons treated with 6OHDA (B), on the survival of GABA neurons (C) and murine mesencephalic embryonic fibroblasts (D). The influence of compound $\mathbf{4}$ on phosphorylation of receptors of neurotrophic factors GDNF (E) and BDNF (F). The influence of compound 4 on MAPK/ERK and AKT signaling cascades in murine fibroblasts MG87RET transfected with GDNF family receptor alpha 1 (GFR $\alpha 1)(G)$ or in neuroblastoma Neuro 2A cells $(\mathrm{H})$ shown by Western blotting. Quantitative analysis of pAKT (I) and pERK (J) levels in Neuro2A cells treated with vehicle or compound 4. Quantitative data are presented as Mean \pm SEM. IP-immunoprecipitation, WB-Western blotting, pY-phosphotyrosin, GAPDH - Glyceraldehyde 3-phosphate dehydrogenase, loading control, VEH - vehicle. A - * P < 0.05 ANOVA with Dunnett's posthoc test compared to vehicle, $\mathrm{N}=4 ; \mathrm{H}-* \mathrm{P}<0.05$, paired t-test, compared to vehicle, $\mathrm{N}=5$.

\subsection{Evaluation of neuroprotective/neurorestorative properties of diol-epoxide in the nigrostriatal dopamine system.}

According to the in vitro data showing the positive influence of compound $\mathbf{4}$ on the survival of cultured dopamine neurons, we decided to evaluate the neurorestorative properties of diol epoxide in the nigrostriatal dopamine system in vivo in the MPTP-induced mouse model of PD. The bodies of nigrostriatal dopamine neurons are located in the brain region known as substantia nigra

pars compacta (SNpc), while their axons project to the brain region called the striatum. Therefore, we quantified the density of TH-positive fibers in the striatum and the number of TH-positive cells in SNpc. Mice were treated with $4 \times 20 \mathrm{mg}$ of MPTP to induce degeneration of dopamine neurons. Two different doses (5 and $20 \mathrm{mg} / \mathrm{kg}$ ) were used to study the effect of epoxide 4 in this model. 
Epoxide 4 was administered orally to mice $24 \mathrm{~h}$ after the last MPTP injection and then for additional 14 days (5 daily administrations per week for 3 weeks). Mouse brains were collected 30 days after lesion. Administration of MPTP reduced the density of TH-positive fibers in the striatum two-fold as compared to that in vehicle-treated mice (Figure 7A). Treatment of MPTP mice with both 5 and $20 \mathrm{mg} / \mathrm{kg}$ of compound 4 significantly increased the density of TH-positive fibers in the striatum as compared to that in MPTP-treated mice $(P=0.0053$ and $P=0.0329$, respectively, ANOVA with Dunnett's post hoc test) (Figure 7A).

We also studied the effect of epoxide 4 on the number of TH-positive neurons in the SNpc. No statistically significant changes in the number of TH-positive neurons were observed in any treatment group.

The data presented in Figure 6 suggest that compound 4 can either stimulate the outgrowth and arborization of neurites of dopamine neurons in vivo, which is expected to increase the number of dopaminergic synapses in the striatum and halt the disease progression or at least stimulate the expression of $\mathrm{TH}$, that will likely result in the increase of dopamine content in the striatum and alleviate symptoms of PD. It is unclear whether compound 4 can also stimulate regeneration of dopamine cell bodies in SNpc since their loss induced by MPTP in this particular experiment was mild, if any at all. However, we noticed in the in vitro experiments that epoxide 4 is able to activate ERK (Fig 6H, 6J) but not AKT (Fig 6I). In neurons, AKT is the major regulator of neuronal survival, ${ }^{35,36}$ while ERK1/2 is important for neurite growth ${ }^{37}$ rather than for survival. ${ }^{38}$ Thus, the in vitro data showing pERK activation in cultured cells taken together with the results of analyzing the TH-positive fiber density may indicate that the mechanism of neurorestoration induced by epoxide 4 is mediated by ERK and includes stimulation of striatal reinnervation by dopamine neurons.

It is important to mention that neurodegeneration in Parkinson's disease starts from axons. The motor symptoms of PD appear when dopamine concentration in the putamen drops by $70 \%-$ 
$80 \%$. Meanwhile, the loss of dopamine neurons bodies in the SNpc at disease onset is only $30 \%{ }^{3}$. Moreover, some bodies of dopamine neurons remain in the brain of PD patients even at the very late stage (> 20 years after the diagnosis), while dopamine axons in the putamen disappear almost completely within 5 years after diagnosis ${ }^{4}$. Therefore, restoration of axons of dopamine neurons in the putamen can be a valuable therapeutic strategy in PD.

Our results do not give grounds for drawing a conclusion whether epoxide $\mathbf{4}$ is able to protect the bodies of dopamine neurons in SNpc. However, it might protect or stimulate axonal regrowth into the striatum. Therefore, our data and the features of PD progression in patients support further developing epoxide 4 not only as symptomatic treatment but also as a potential neuroprotective/neurorestorative therapeutic agent against PD. 
A
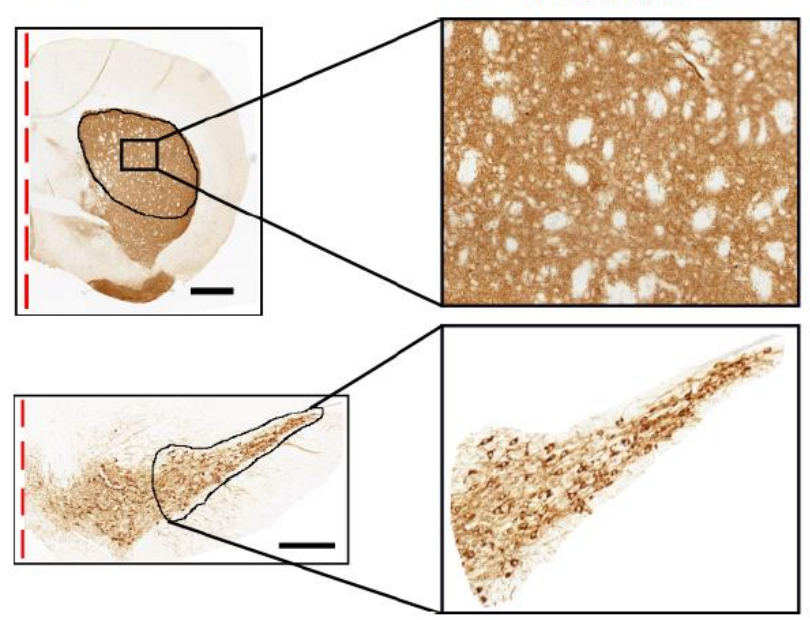

B

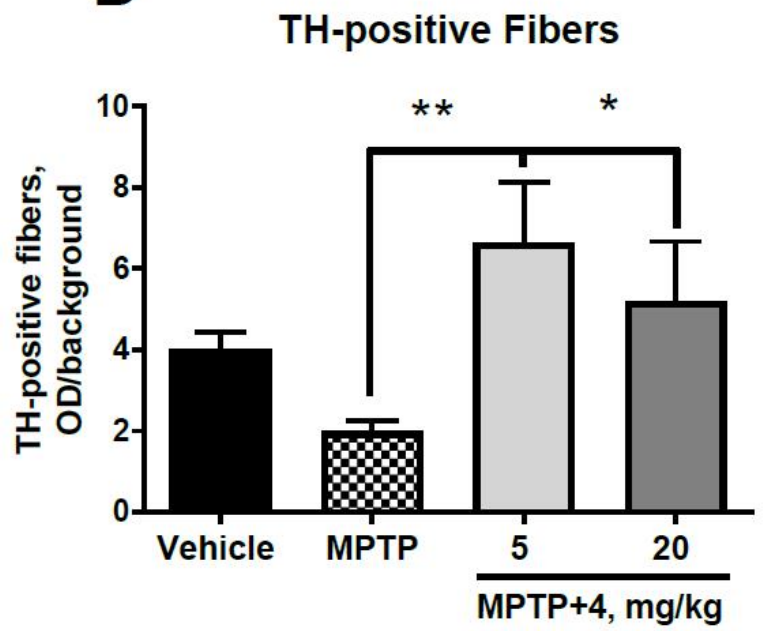

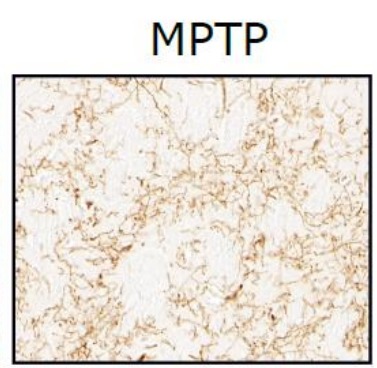
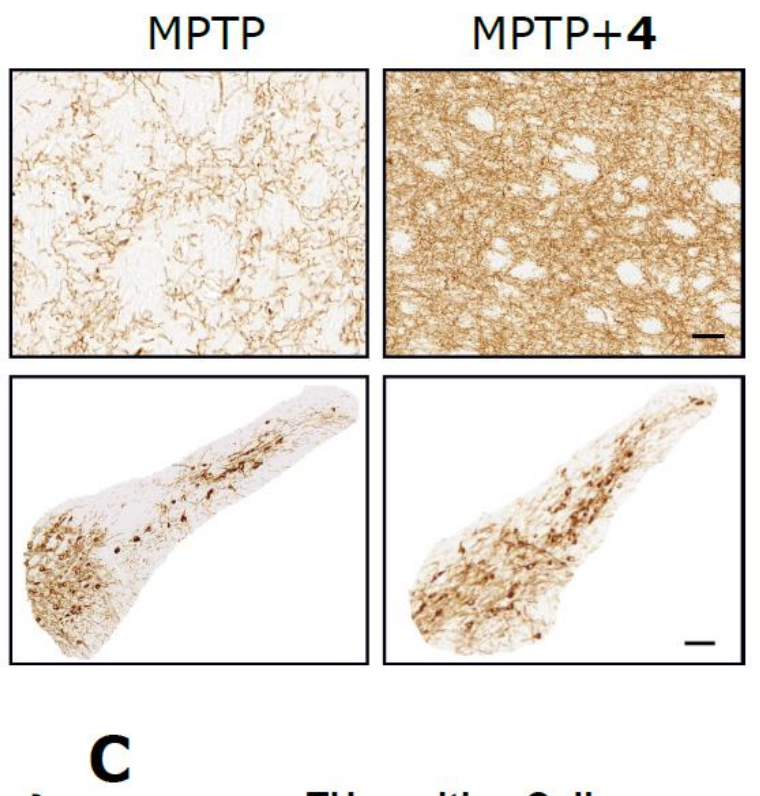

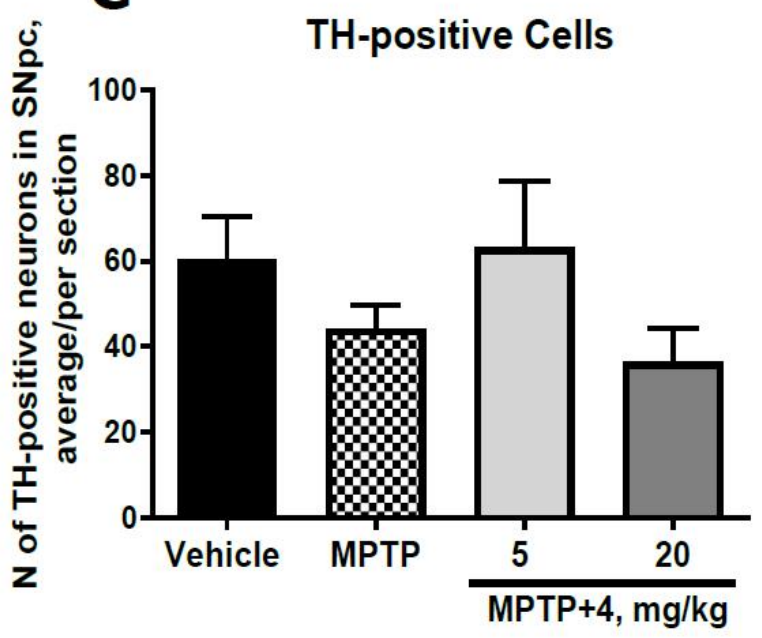

TH-positive Cells

Figure 7. The influence of compound $4(5$ and $20 \mathrm{mg} / \mathrm{kg})$ on the density of TH-positive fibers in the striatum $(\mathbf{A}, \mathbf{B})$ and the number of TH-positive cells $(\mathbf{C})$ in SNpc of MPTP-treated $(4 \times 0.12 \mathrm{mmol} / \mathrm{kg}$ $(4 \times 20 \mathrm{mg} / \mathrm{kg}))$ male $\mathrm{C} 57 \mathrm{Bl} / 6$ mice. The data are presented as Mean $\pm \mathrm{SEM}, \mathrm{N}=3-6$ per group. $* P$ $<0.05,{ }^{*} P<0.01$ compared to the MPTP group, ANOVA with Dunnett's post hoc test. Scale bar: $40 \mu \mathrm{M}$.

\subsection{Conclusions}

All four isomeric epoxides of $(1 R, 2 R, 6 S)$-3-methyl-6-(prop-1-en-2-yl)cyclohex-3-ene-1,2diol 1 have been synthesized. Epoxidation of double bonds at positions 3,4 (epoxide 4) and 7,8 
(epoxide 7) was found to give rise to biologically active compounds capable of restoring the locomotor activity in the MPTP-induced mouse model of PD. Epoxide 4 was identified to be an active metabolite of $\mathbf{1}$. Both these compounds were able to penetrate the blood-brain barrier, but epoxide 4 did so with higher efficacy. Moreover, epoxide 4 remained in the circulation longer than epoxide 7 did. Interestingly, epoxide $\mathbf{4}$ is also a metabolite of diol $\mathbf{1}$ found in vivo. Based on all these data, we selected epoxide 4 to study the possible mechanism of its biological activity in the PD model. We found that epoxide 4 protects cultured dopamine neurons against spontaneous and toxininduced death, and selectively activates ERK in the cells of neuronal origin. In animals treated with MPTP, epoxide 4 increases the density of TH positive fibers in the striatum. Our data indicate that epoxide 4 may produce positive immediate and long-term effects in the PD model; the later ones might berelated to neurorestoration. Hence, epoxide 4 may encourage the development of diseasemodifying treatment against PD.

\section{Methods}

3.1. General methods and materials: Reagents and solvents were purchased from commercial suppliers and used as received. Dry solvents were obtained according to the standard procedures. $(1 R, 2 R, 6 S)-3-M e t h y l-6-(p r o p-1-e n-2-y l) c y c l o h e x-3-e n e-1,2-d i o l(\mathbf{1})\left([\alpha]_{D}^{31}-49.1\right.$ (c 2.6, $\left.\left.\mathrm{CHCl}_{3}\right)\right)$ was synthesized from (-)-verbenone (Aldrich) $\left([\alpha]_{D}^{25}-210.5\left(c \quad 0.77, \mathrm{CHCl}_{3}\right)\right)$ according to previously described procedure..$^{39,40}$

Spectral and analytical investigations were carried out at Collective Chemical Service center of Siberian Branch of Russian Academy of Sciences. ${ }^{1} \mathrm{H}$ - and ${ }^{13} \mathrm{C}-\mathrm{NMR}$ Spectra: Bruker DRX-500 apparatus at $500.13 \mathrm{MHz}\left({ }^{1} \mathrm{H}\right)$ and $125.76 \mathrm{MHz}\left({ }^{13} \mathrm{C}\right)$ in $\mathrm{CDCl}_{3}, \mathrm{CDCl}_{3} / \mathrm{CCl}_{4} 1: 1$ (v/v)or $\mathrm{CDCl}_{3} /$ $\mathrm{CD}_{3} \mathrm{OD} 10: 1(\mathrm{v} / \mathrm{v})$; chemical shifts $\delta$ in ppm rel. to residual $\mathrm{CHCl}_{3}[\delta(\mathrm{H}) 7.24, \delta(\mathrm{C}) 76.90 \mathrm{ppm}], J$ in Hz. The structure of the products was determined by analyzing the ${ }^{1} \mathrm{H}$ - and ${ }^{13} \mathrm{C}-\mathrm{NMR}$ spectra, 
${ }^{1} \mathrm{H},{ }_{1}^{1} \mathrm{H}$ double-resonance spectra and ${ }^{13} \mathrm{C},{ }^{1} \mathrm{H}$-type $2 \mathrm{D}$-COSY $(J(\mathrm{C}, \mathrm{H})=135 \mathrm{~Hz})$. NMR spectra for compounds 6 and 7: Bruker AV-600 spectrometer (resonance frequency for ${ }^{1} \mathrm{H} 600.30 \mathrm{MHz}$, for ${ }^{13} \mathrm{C}$ 150.95 MHz). Chemical shifts for ${ }^{1} \mathrm{H}$ and ${ }^{13} \mathrm{C}$ measured relative to the internal standard $\mathrm{CDCl}_{3}(\delta$ $7.24 \mathrm{ppm}$ for ${ }^{1} \mathrm{H}, 76.90 \mathrm{ppm}$ for ${ }^{13} \mathrm{C}$ ). For structure determination and NMR signal assignment in 6 and 7 2D correlation spectra ${ }^{1} \mathrm{H}-{ }^{1} \mathrm{H}$ (COSY, NOESY) and ${ }^{1} \mathrm{H}-{ }^{13} \mathrm{C}$ (HSQC, HMBC) were used. GC: 7820A gas chromatograph (Agilent Tech., USA); flame-ionization detector; HP-5 capillary column $(0.25 \mathrm{mmol} \varnothing \times 30 \mathrm{~m} \times 0.25 \mu \mathrm{m}), \mathrm{He}$ as carrier gas (flow rate $2 \mathrm{ml} / \mathrm{min}$, flow division $99: 1)$. GC/MS: Agilent 7890A with a quadrupole mass spectrometer Agilent 5975C as a detector, HP-5MS quartz column, 30000x0.25 mm, He (1 atm) as carrier gas. Optical rotation: polAAr 3005 spectrometer; $\mathrm{CHCl}_{3}$ soln. HR-MS: DFS Thermo Scientific spectrometer in a full scan mode (15$500 \mathrm{~m} / \mathrm{z}, 70 \mathrm{eV}$ electron impact ionization, direct sample administration).

Conformational analysis of the epoxides 6 and 7 was performed with the computer program packages ChemAxon Marvin, ${ }^{41}$ VeraChem Vconf ${ }^{42}$ and Tinker. ${ }^{43}$ The geometries of all the conformers were optimized by DFT (Priroda program, ${ }^{44,45} \mathrm{PBE}$ functional, ${ }^{46} \mathrm{~L} 1$ basis $\left(\Lambda 01,{ }^{47} \mathrm{cc}-\right.$ pVDZ analog). Quantum chemical calculations were carried out on the computational cluster at the Information Computation Center, Novosibirsk State University. The purity of the target compounds was determined by gas chromatography methods. All of the target compounds reported in this paper have a purity of no less than $95 \%$ (GC-MS data). Target compounds successfully passed the virtual filter for known classes of assay interference compounds (PAINS). ${ }^{48}$

3.2. (1S,2S,3R,4S,6R)-1-methyl-4-(prop-1-en-2-yl)-7-oxabicyclo[4.1.0]heptane-2,3-diol (4) and (1R,2S,3R,4S,6S)-1-methyl-4-(prop-1-en-2-yl)-7-oxabicyclo[4.1.0]heptane-2,3-diol (5).

3.2.1. Epoxidation of (1R,2R,6S)-3-methyl-6-(prop-1-en-2-yl)cyclohex-3-ene-1,2-diol (1) with peracetic acid. Method a (Scheme 1). A mixture of $\mathrm{AcOH}(200 \mathrm{ml}), 35 \% \mathrm{H}_{2} \mathrm{O}_{2}(200 \mathrm{ml})$ and 
$\mathrm{H}_{2} \mathrm{SO}_{4}(5 \mathrm{ml})$ was stored for 5 days. Then a part of this mixture $(100 \mathrm{ml})$ was extracted with $\mathrm{CH}_{2} \mathrm{Cl}_{2}$ ( $2 \times 50 \mathrm{ml}$ ) and combined extract was dried over $\mathrm{MgSO}_{4}$. The concentration of AcOOH was 0.0925 moles per $100 \mathrm{ml}$ of the solution. Grinded $\mathrm{Na}_{2} \mathrm{CO}_{3}(2 \mathrm{~g})$ and then the AcOOH solution $(7 \mathrm{ml}, 0.648$ mmol) were added under stirring to the solution of diol $\mathbf{1}(1.00 \mathrm{~g}, 5.95 \mathrm{mmol})$ in $\mathrm{CH}_{2} \mathrm{Cl}_{2}(4 \mathrm{ml})$. The reaction mixture was stirred for $3 \mathrm{~h}$, diluted with water $(40 \mathrm{ml})$, separated, and the water phase was extracted with $\mathrm{CH}_{2} \mathrm{Cl}_{2}(3 \times 20 \mathrm{ml})$ and EtOAc $(3 \times 30 \mathrm{ml})$. The combined organic layers were desiccated over $\mathrm{Na}_{2} \mathrm{CO}_{3}$. The desiccant was filtered off, the solvent was evaporated. The residue (762 mg) was separated by CC on silica gel (17 g) using 0-100\% EtOAc gradient in hexane as eluent. This procedure gave starting diol 1 (64 mg, $0.38 \mathrm{mmol}$, conv. 94\%), (1S,2S,3R,4S,6R)-1methyl-4-(prop-1-en-2-yl)-7-oxabicyclo[4.1.0]heptane-2,3-diol (4, 179 mg, 0.973 mmol, $16 \%$ calculated on reacted diol 1) and $(1 R, 2 S, 3 R, 4 S, 6 S)$-1-methyl-4-(prop-1-en-2-yl)-7oxabicyclo[4.1.0]heptane-2,3-diol (5, $40 \mathrm{mg}, 0.217 \mathrm{mmol}, 4 \%)$

Compound 4. $[\alpha]_{\mathrm{D}}{ }^{24}-19.8\left(\mathrm{c} 1.06, \mathrm{CHCl}_{3}\right) .{ }^{1} \mathrm{H}$ NMR $\left(500 \mathrm{MHz}, \mathrm{CDCl}_{3} / \mathrm{CCl}_{4} 1: 1(\mathrm{v} / \mathrm{v})\right): \delta$ $1.44\left(\mathrm{~s}, \mathrm{C}^{10} \mathrm{H}_{3}\right), 1.77\left(\mathrm{~s}, \mathrm{C}^{9} \mathrm{H}_{3}\right), 1.88\left(\mathrm{ddd}, \mathrm{H}^{5 \mathrm{e}}, J_{5 \mathrm{e}, 5 \mathrm{a}}=14.7, J_{5 \mathrm{e}, 6 \mathrm{a}}=4.5, J_{5 \mathrm{e}, 4}=2.2 \mathrm{~Hz}\right), 2.07$ (ddd, $\left.\mathrm{H}^{5 \mathrm{a}}, J_{5 \mathrm{a}, 5 \mathrm{e}}=14.7, J_{5 \mathrm{a}, 6 \mathrm{a}}=12.0, J_{5 \mathrm{a}, 4}=1.9 \mathrm{~Hz}\right), 2.21\left(\mathrm{dd}, \mathrm{H}^{6 \mathrm{a}}, J_{6 \mathrm{a}, 5 \mathrm{a}}=12.0, J_{6 \mathrm{a}, 5 \mathrm{e}}=4.5 \mathrm{~Hz}\right), 2.29\left(\mathrm{~d}, \mathrm{C}^{1}-\right.$ $\left.\mathrm{OH}, J_{\mathrm{OH}, 1 \mathrm{e}}=10.0 \mathrm{~Hz}\right), 3.31\left(\mathrm{dd}, \mathrm{H}^{4}, J_{4,5 \mathrm{e}}=2.2, J_{4,5 \mathrm{a}}=1.9 \mathrm{~Hz}\right), 3.58\left(\mathrm{~s}, \mathrm{H}^{2 \mathrm{e}}\right), 3.76\left(\mathrm{dd}, \mathrm{H}^{1 \mathrm{e}}, J_{1 \mathrm{e}, \mathrm{OH}}=\right.$ 10.0, $J_{1 \mathrm{e}, 2 \mathrm{e}}=2.5 \mathrm{~Hz}$ ), 4.79 (br. s, $\left.\mathrm{H}^{8}\right), 4.94$ (br. s, $\mathrm{H}^{8}$ ). ${ }^{13} \mathrm{C} \mathrm{NMR}\left(125 \mathrm{MHz}, \mathrm{CDCl}_{3} / \mathrm{CCl}_{4} 1: 1\right.$ (v/v)): $\delta 71.32\left(\mathrm{~d}, \mathrm{C}^{1}\right), 69.43\left(\mathrm{~d}, \mathrm{C}^{2}\right), 58.44\left(\mathrm{~s}, \mathrm{C}^{3}\right), 63.32\left(\mathrm{~d}, \mathrm{C}^{4}\right), 23.12\left(\mathrm{t}, \mathrm{C}^{5}\right), 35.95\left(\mathrm{~d}, \mathrm{C}^{6}\right), 144.98\left(\mathrm{~s}, \mathrm{C}^{7}\right)$, $111.78\left(\mathrm{t}, \mathrm{C}^{8}\right), 22.92\left(\mathrm{q}, \mathrm{C}^{9}\right), 22.17\left(\mathrm{q}, \mathrm{C}^{10}\right)$. HR-MS: $166.1000\left(M^{+}-\mathrm{H}_{2} \mathrm{O}, \mathrm{C}_{10} \mathrm{H}_{14} \mathrm{O}_{2}\right.$; calc. 166.0988). Compound 5. $[\alpha]_{\mathrm{D}}{ }^{26}-24.1$ (c $\left.0.64, \mathrm{CHCl}_{3}\right) .{ }^{1} \mathrm{H} \mathrm{NMR}\left(500 \mathrm{MHz}, \mathrm{CDCl}_{3} / \mathrm{CCl}_{4} 1: 1\right.$ (v/v)): $\delta$ $1.38\left(\mathrm{~s}, \mathrm{C}^{10} \mathrm{H}_{3}\right), 1.75\left(\mathrm{~s}, \mathrm{C}^{9} \mathrm{H}_{3}\right), 2.02\left(\mathrm{dddd}, \mathrm{H}^{5 \mathrm{e}}, J_{5 \mathrm{e}, 5 \mathrm{a}}=15.8, J_{5 \mathrm{e}, 6 \mathrm{a}}=7.5, J_{5 \mathrm{e}, 4}=5.0, J_{5 \mathrm{e}, 1 \mathrm{e}}=0.6 \mathrm{~Hz}\right)$, $2.07\left(\mathrm{dd}, \mathrm{H}^{5 \mathrm{a}}, J_{5 \mathrm{a}, 5 \mathrm{e}}=15.8, J_{5 \mathrm{a}, 6 \mathrm{a}}=12.0 \mathrm{~Hz}\right), 2.37\left(\mathrm{dd}, \mathrm{H}^{6 \mathrm{a}}, J_{6 \mathrm{a}, 5 \mathrm{a}}=12.0, J_{6 \mathrm{a}, 5 \mathrm{e}}=7.5 \mathrm{~Hz}\right), 3.09\left(\mathrm{~d}, \mathrm{C}^{1}-\right.$ $\left.\mathrm{OH}, J_{\mathrm{OH}, 1 \mathrm{e}}=11.3 \mathrm{~Hz}\right), 3.16\left(\mathrm{~d}, \mathrm{H}^{4}, J_{4,5 \mathrm{e}}=5.0 \mathrm{~Hz}\right), 3.32\left(\right.$ br. s, $\left.\mathrm{C}^{2}-\mathrm{OH}\right), 3.62\left(\mathrm{dm}, \mathrm{H}^{3 \mathrm{e}}, J_{3 \mathrm{e}, \mathrm{OH}}=11.3\right.$ $\mathrm{Hz}), 3.93\left(\right.$ br. s, $\left.\mathrm{H}^{2 \mathrm{e}}\right), 4.78\left(\mathrm{dd}, \mathrm{H}^{8}, J_{8,8^{\prime}}=1.7, J_{8,6 \mathrm{a}}=0.7 \mathrm{~Hz}\right), 4.84\left(\mathrm{dd}, \mathrm{H}^{8^{\prime}}, J_{8^{\prime}, 8}=1.7, J_{8^{\prime}, 6 \mathrm{a}}=1.5\right.$ 
Hz). ${ }^{13} \mathrm{C}$ NMR (125 MHz, $\left.\mathrm{CDCl}_{3} / \mathrm{CCl}_{4} 1: 1(\mathrm{v} / \mathrm{v})\right): \delta 73.39\left(\mathrm{~d}, \mathrm{C}^{1}\right), 70.19\left(\mathrm{~d}, \mathrm{C}^{2}\right), 60.83\left(\mathrm{~s}, \mathrm{C}^{3}\right)$, $60.43\left(\mathrm{~d}, \mathrm{C}^{4}\right), 23.67\left(\mathrm{t}, \mathrm{C}^{5}\right), 37.42\left(\mathrm{~d}, \mathrm{C}^{6}\right), 145.24\left(\mathrm{~s}, \mathrm{C}^{7}\right), 111.74\left(\mathrm{t}, \mathrm{C}^{8}\right), 22.01\left(\mathrm{q}, \mathrm{C}^{9}\right), 19.85\left(\mathrm{q}, \mathrm{C}^{10}\right)$. HR-MS: $184.1100\left(M^{+}, \mathrm{C}_{10} \mathrm{H}_{16} \mathrm{O}_{3}\right.$; calc. 184.1094).

3.2.2. Epoxidation of (1R,2R,6S)-3-methyl-6-(prop-1-en-2-yl)cyclohex-3-ene-1,2-diol (1) with $m-C P B A$.

Method b (Scheme 1). A solution of diol 1 (0.312 g, $1.86 \mathrm{mmol})$ in $\mathrm{CH}_{2} \mathrm{Cl}_{2}$ (40 ml) was cooled to $0^{\circ} \mathrm{C} . \mathrm{NaHCO}_{3}(1.55 \mathrm{~g}, 18.5 \mathrm{mmol})$ and m-CPBA (m-Cl-C $6 \mathrm{H}_{4}-\mathrm{CO}_{3} \mathrm{H}$, "Acros Organics" $0.589 \mathrm{~g}, 70-75 \%$ of content, $\sim 2.5 \mathrm{mmol}$ ) were added and the reaction mixture was stored in refrigerator $\left(2-5^{\circ} \mathrm{C}\right)$ for 1 week. Then water $(30 \mathrm{ml})$ was added and the resulting mixture was filtered and separated. The water phase was extracted with EtOAc ( 3 x $15 \mathrm{ml})$ Combined organic layers were washed with saturated $\mathrm{Na}_{2} \mathrm{~S}_{2} \mathrm{O}_{3}(15 \mathrm{ml})$ and saturated $\mathrm{NaCl}(20 \mathrm{ml})$ and dessicated over $\mathrm{Na}_{2} \mathrm{SO}_{4}$. The desiccant was filtered off, the solvent was evaporated. The residue (293 mg) was separated by CC on silica gel (9 g) using 0-100\% EtOAc gradient in hexane as eluent. This procedure gave starting diol 1 ( $28 \mathrm{mg}, 0.17 \mathrm{mmol}$, conv. 91\%), the epoxide 4 (82 $\mathrm{mg}, 0.446 \mathrm{mmol}$, $26 \%$ calculated on reacted diol 1) the epoxide $5(34 \mathrm{mg}, 0.185 \mathrm{mmol}, 11 \%)$ and the epoxide 7 (10 mg with impurities, 0.04-0.05 mmol, 2-3\%).

Method c (Scheme 1). A solution of diol 1 (458 $\mathrm{mg}, 2.73 \mathrm{mmol})$ in $\mathrm{Et}_{2} \mathrm{O}$ (30 ml) was cooled to $0^{\circ} \mathrm{C}$. Then m-CPBA (“Acros Organics" $982 \mathrm{mg}, 70-75 \%$ of content, $\sim 4.2 \mathrm{mmol}$ ) was added and the reaction mixture was stored in refrigerator $\left(2-5^{\circ} \mathrm{C}\right)$ for 3 week. The solvent was evaporated and the residue was separated by CC on silica gel (17 g) using 0-100\% EtOAc gradient in hexane as eluent. This procedure gave the epoxide 4 (161 mg, $0.875 \mathrm{mmol}, 32 \%)$ epoxide 5 (49 $\mathrm{mg}, 0.266$ mmol, 10\%) and $230 \mathrm{mg}(1.15 \mathrm{mmol}, 42 \%)$ of the mixture of four stereoisomeric diepoxides $\mathbf{8}$. The formation of diepoxides is confirmed by the signals of oxirane cycle at $2.5-3.5 \mathrm{ppm}$ and by the absence of signals related to double bounds at 4.6-6 ppm in ${ }^{1} \mathrm{H}$ NMR spectra. 


\section{3. (1R,2R,6R)-3-methyl-6-((R)-2-methyloxiran-2-yl)cyclohex-3-ene-1,2-diol (6) and (1R,2R,6R)-}

3-methyl-6-((S)-2-methyloxiran-2-yl)cyclohex-3-ene-1,2-diol (7).

3.3.1. Interaction of diol 1 with iodine. Iodine $(811.4 \mathrm{mg}, 3.197 \mathrm{mmol})$ was grinded in a mortar and dissolved in EtOAc $(5 \mathrm{ml})$. Acetic acid $(1.0 \mathrm{ml})$ and water $(3 \mathrm{ml})$ were added. Then a solution of $(1 R, 2 R, 6 S)$-3-methyl-6-(prop-1-en-2-yl)cyclohex-3-ene-1,2-diol $(\mathbf{1}, 523.6 \mathrm{mg}, 3.113$ mmol) in $10 \mathrm{ml}$ EtOAc was added. The reaction mixture was stirred for 5 days at r.t. Then it was washed with saturated solutions of $\mathrm{NaHCO}_{3}\left(2 \times 20 \mathrm{ml}\right.$, add slowly) and $\mathrm{Na}_{2} \mathrm{~S}_{2} \mathrm{O}_{3}$ (10 ml).The organic phase was desiccated over $\mathrm{Na}_{2} \mathrm{SO}_{4}$. The desiccant was filtered off, the solvent was evaporated. The residue $(682.8 \mathrm{mg})$ was separated by CC on silica gel (20 g) using $0-100 \%$ EtOAc gradient in hexane as eluent. This procedure gave starting diol 1 (326.3 mg, $1.940 \mathrm{mmol}$, conv. 62\%), (1R,2R,6R)-6-((S)-2-hydroxy-1-iodopropan-2-yl)-3-methylcyclohex-3-ene-1,2-diol (9, 176.1 $\mathrm{mg}, 0.564 \mathrm{mmol}, 29 \%$ calculated on consumed diol 1), $(1 R, 2 R, 6 R)-6-((R)-2$-hydroxy-1-iodopropan2-yl)-3-methylcyclohex-3-ene-1,2-diol (10,69.4 mg, $0.208 \mathrm{mmol}, 11 \%$ calculated on reacted diol 1), $(1 R, 5 S, 6 R)$-6-hydroxy-2-methyl-5-(prop-1-en-2-yl)cyclohex-2-enyl acetate (11, $48.2 \mathrm{mg}, 0.229$ mmol, $12 \%)$ and $(1 R, 2 R, 6 S)$-2-hydroxy-3-methyl-6-(prop-1-en-2-yl)cyclohex-3-enyl acetate (12, $17.9 \mathrm{mg}, 0.085 \mathrm{mmol}, 4 \%)$.

Compound 9. ${ }^{1} \mathrm{H}$ NMR $\left(500 \mathrm{MHz}, \mathrm{CDCl}_{3}\right): \delta 1.52\left(\mathrm{~s}, \mathrm{C}^{9} \mathrm{H}_{3}\right), 1.73$ (br. d, $\mathrm{C}^{2}-\mathrm{OH}, J_{\mathrm{OH}, 2 \mathrm{e}}=5.0$ $\mathrm{Hz}), 1.82\left(\mathrm{~m}, \mathrm{C}^{10} \mathrm{H}_{3}\right.$, all $\left.\mathrm{J} \leq 2.5 \mathrm{~Hz}\right), 2.00-2.09\left(\mathrm{~m}, \mathrm{H}^{5 \mathrm{e}}, \mathrm{H}^{6 \mathrm{a}}\right), 2.25-2.35\left(\mathrm{~m}, \mathrm{H}^{5 \mathrm{a}}\right), 2.90$ (br. s, $\mathrm{C}^{7}-$ $\mathrm{OH}), 3.01$ (br. d, $\left.\mathrm{C}^{1}-\mathrm{OH}, J_{\mathrm{OH}, 1 \mathrm{e}}=3.4 \mathrm{~Hz}\right), 3.24\left(\mathrm{~d}, \mathrm{H}^{8},{ }^{2} J=10.1 \mathrm{~Hz}\right), 3.42\left(\mathrm{~d}, \mathrm{H}^{8^{\prime}},{ }^{2} J=10.1 \mathrm{~Hz}\right), 3.81$ (br. dd, $\left.\mathrm{H}^{2 \mathrm{e}}, J_{2 \mathrm{e}, \mathrm{OH}}=5.0, J_{2 \mathrm{e}, 1 \mathrm{e}}=3.0 \mathrm{~Hz}\right), 4.30\left(\mathrm{ddd}, \mathrm{H}^{1 \mathrm{e}}, J_{1 \mathrm{e}, \mathrm{OH}}=3.4, J_{1 \mathrm{e}, 2 \mathrm{e}}=3.0, J_{1 \mathrm{e}, 6 \mathrm{a}}=1.5 \mathrm{~Hz}\right)$, $5.65-5.69\left(\mathrm{~m}, \mathrm{H}^{4}\right) .{ }^{13} \mathrm{C}$ NMR $\left(125 \mathrm{MHz}, \mathrm{CDCl}_{3}\right): \delta 71.26\left(\mathrm{~d}, \mathrm{C}^{1}\right), 72.08\left(\mathrm{~d}, \mathrm{C}^{2}\right), 131.14\left(\mathrm{~s}, \mathrm{C}^{3}\right)$, $125.16\left(\mathrm{~d}, \mathrm{C}^{4}\right), 20.71\left(\mathrm{t}, \mathrm{C}^{5}\right), 37.37\left(\mathrm{~d}, \mathrm{C}^{6}\right), 73.44\left(\mathrm{~s}, \mathrm{C}^{7}\right), 18.39\left(\mathrm{t}, \mathrm{C}^{8}\right), 27.15\left(\mathrm{q}, \mathrm{C}^{9}\right), 20.87\left(\mathrm{q}, \mathrm{C}^{10}\right)$. HR-MS: $294.0109\left(M^{+}-\mathrm{H}_{2} \mathrm{O}, \mathrm{C}_{10} \mathrm{H}_{15} \mathrm{O}_{2} \mathrm{I}\right.$; calc. 294.0111). 
Compound 10. $[\alpha]_{\mathrm{D}^{26}}-36.7$ (c $0.463, \mathrm{CHCl}_{3}$ ). ${ }^{1} \mathrm{H} \mathrm{NMR}\left(500 \mathrm{MHz}, \mathrm{CDCl}_{3} / \mathrm{CD}_{3} \mathrm{OD}\right.$ ): $\delta 1.30$ (s, $\left.\mathrm{C}^{9} \mathrm{H}_{3}\right), 1.75\left(\mathrm{~m}, \mathrm{C}^{10} \mathrm{H}_{3}\right.$, all $\left.\mathrm{J} \leq 2.5 \mathrm{~Hz}\right), 2.01\left(\mathrm{dddq}, \mathrm{H}^{5 e},{ }^{2} J=17.6, J_{5 \mathrm{e}, 6 \mathrm{a}} 5.6, J_{5 \mathrm{e}, 4}=5.3, J_{5 \mathrm{e}, 10}=1.6\right.$ $\mathrm{Hz}), 2.12\left(\mathrm{ddd}, \mathrm{H}^{6 \mathrm{a}}, J_{6 \mathrm{a}, 5 \mathrm{a}}=11.3, J_{6 \mathrm{a}, 5 \mathrm{e}}=5.6, J_{6 \mathrm{a}, 1 \mathrm{e}}=1.8 \mathrm{~Hz}\right), 2.26\left(\mathrm{dddqd}, \mathrm{H}^{5 \mathrm{a}},{ }^{2} J=17.6, J_{5 \mathrm{a}, 6 \mathrm{a}}=\right.$ $\left.11.3, J_{5 \mathrm{a}, 4}=J_{5 \mathrm{a}, 10}=2.5, J_{5 \mathrm{a}, 2 \mathrm{e}}=1.3 \mathrm{~Hz}\right), 3.35\left(\mathrm{dd}, \mathrm{H}^{8},{ }^{2} J=10.2, J_{8,9}=0.6 \mathrm{~Hz}\right), 3.39\left(\mathrm{~d}, \mathrm{H}^{8},{ }^{2} J=10.2\right.$ $\mathrm{Hz}), 3.64\left(\mathrm{br} . \mathrm{d}, \mathrm{H}^{2 \mathrm{e}}, J_{2 \mathrm{e}, 1 \mathrm{e}}=2.7 \mathrm{~Hz}\right), 4.10\left(\mathrm{dd}, \mathrm{H}^{1 \mathrm{e}}, J_{1 \mathrm{e}, 2 \mathrm{e}}=2.7, J_{1 \mathrm{e}, 6 \mathrm{a}}=1.8 \mathrm{~Hz}\right), 5.62\left(\mathrm{ddq}, \mathrm{H}^{4}, J_{4,5 \mathrm{e}}=\right.$ $\left.5.3, J_{4,5 \mathrm{a}}=2.5, J_{4,10}=1.5 \mathrm{~Hz}\right) .{ }^{13} \mathrm{C} \mathrm{NMR}\left(125 \mathrm{MHz}, \mathrm{CDCl}_{3} / \mathrm{CD}_{3} \mathrm{OD}\right): \delta 70.40\left(\mathrm{~d}, \mathrm{C}^{1}\right), 71.99\left(\mathrm{~d}, \mathrm{C}^{2}\right)$, $130.85\left(\mathrm{~s}, \mathrm{C}^{3}\right), 125.18\left(\mathrm{~d}, \mathrm{C}^{4}\right), 21.66\left(\mathrm{t}, \mathrm{C}^{5}\right), 36.17\left(\mathrm{~d}, \mathrm{C}^{6}\right), 73.04\left(\mathrm{~s}, \mathrm{C}^{7}\right), 17.79\left(\mathrm{t}, \mathrm{C}^{8}\right), 25.19\left(\mathrm{q}, \mathrm{C}^{9}\right)$, $20.73\left(\mathrm{q}, \mathrm{C}^{10}\right)$. HR-MS: $294.0110\left(M^{+}-\mathrm{H}_{2} \mathrm{O}, \mathrm{C}_{10} \mathrm{H}_{15} \mathrm{O}_{2} \mathrm{I}\right.$; calc. 294.0111).

Compound 11. ${ }^{1} \mathrm{H}$ NMR $\left(500 \mathrm{MHz}, \mathrm{CDCl}_{3}\right): \delta 1.67\left(\mathrm{~d}, \mathrm{C}^{1}-\mathrm{OH}, J_{\mathrm{OH}, \mathrm{le}}=4.0 \mathrm{~Hz}\right), 1.69(\mathrm{~m}$, $\mathrm{C}^{10} \mathrm{H}_{3}$, all $\left.\mathrm{J} \leq 2.5 \mathrm{~Hz}\right), 1.79\left(\mathrm{~m}, \mathrm{C}^{9} \mathrm{H}_{3}\right.$, all $\left.J<2.0 \mathrm{~Hz}\right), 2.03\left(\mathrm{dddq}, \mathrm{H}^{5 \mathrm{e}},{ }^{2} J=17.3, J_{5 \mathrm{e}, 4}=5.3, J_{5 \mathrm{e}, 6 \mathrm{a}}=\right.$ $\left.4.6, J_{5 \mathrm{e}, 10}=1.5 \mathrm{~Hz}\right), 2.08\left(\mathrm{~s}, \mathrm{C}^{12} \mathrm{H}_{3}\right), 2.26\left(\mathrm{dddqd}, \mathrm{H}^{5 \mathrm{a}},{ }^{2} J=17.3, J_{5 \mathrm{a}, 6 \mathrm{a}}=11.4, J_{5 \mathrm{a}, 4}=J_{5 \mathrm{a}, 10}=2.5, J_{5 \mathrm{a}, 2 \mathrm{e}}\right.$ $=1.5 \mathrm{~Hz}), 2.33$ (br. dd, $\left.\mathrm{H}^{6 \mathrm{a}}, J_{6 \mathrm{a}, 5 \mathrm{a}}=11.4, J_{6 \mathrm{a}, 5 \mathrm{e}}=4.6 \mathrm{~Hz}\right), 3.91\left(\mathrm{ddd}, \mathrm{H}^{1 \mathrm{e}}, J_{1 \mathrm{e}, \mathrm{OH}}=4.0, J_{1 \mathrm{e}, 2 \mathrm{e}}=2.6\right.$, $\left.J_{\mathrm{le}, 6 \mathrm{a}}=1.7 \mathrm{~Hz}\right), 4.85\left(\mathrm{~m}, \mathrm{H}^{8}\right.$, all $\left.J<2.0 \mathrm{~Hz}\right), 4.96\left(\mathrm{~m}, \mathrm{H}^{8}\right.$, all $\left.J<2.0 \mathrm{~Hz}\right), 5.10-5.12\left(\mathrm{~m}, \mathrm{H}^{2 \mathrm{e}}\right.$, all $J<$ $3.0 \mathrm{~Hz}), 5.76-5.79\left(\mathrm{~m}, \mathrm{H}^{4}\right) .{ }^{13} \mathrm{C} \mathrm{NMR}\left(125 \mathrm{MHz}, \mathrm{CDCl}_{3}\right): \delta 68.57\left(\mathrm{~d}, \mathrm{C}^{1}\right), 73.00\left(\mathrm{~d}, \mathrm{C}^{2}\right), 128.32(\mathrm{~s}$, $\left.\mathrm{C}^{3}\right), 127.57\left(\mathrm{~d}, \mathrm{C}^{4}\right), 24.28\left(\mathrm{t}, \mathrm{C}^{5}\right), 40.50\left(\mathrm{~d}, \mathrm{C}^{6}\right), 145.17\left(\mathrm{~s}, \mathrm{C}^{7}\right), 111.59\left(\mathrm{t}, \mathrm{C}^{8}\right), 22.36\left(\mathrm{q}, \mathrm{C}^{9}\right), 20.52(\mathrm{q}$, $\left.\mathrm{C}^{10}\right), 170.45$ (s, $\left.\mathrm{C}^{11}\right), 21.01$ (q, $\left.\mathrm{C}^{12}\right)$. HR-MS: $168.1149\left(M^{+}, \mathrm{C}_{10} \mathrm{H}_{16} \mathrm{O}_{2}\right.$; calc. 168.1145). HR-MS: $168.1145\left(M^{+}-\mathrm{C}_{2} \mathrm{H}_{2} \mathrm{O}, \mathrm{C}_{10} \mathrm{H}_{16} \mathrm{O}_{2}\right.$; calc. 168.1145).

Compound 12. ${ }^{1} \mathrm{H}$ NMR $\left(500 \mathrm{MHz}, \mathrm{CDCl}_{3}\right): \delta 1.77\left(\mathrm{~m}, \mathrm{C}^{9} \mathrm{H}_{3}\right.$, all $\left.J<2.0 \mathrm{~Hz}\right), 1.78(\mathrm{~m}$, $\mathrm{C}^{10} \mathrm{H}_{3}$, all $\left.\mathrm{J} \leq 2.5 \mathrm{~Hz}\right), 1.98\left(\mathrm{~s}, \mathrm{C}^{12} \mathrm{H}_{3}\right), 2.03\left(\mathrm{dddq}, \mathrm{H}^{5 \mathrm{e}},{ }^{2} J=17.6, J_{5 \mathrm{e}, 6 \mathrm{a}}=J_{5 \mathrm{e}, 4}=5.3, J_{5 \mathrm{e}, 10}=1.5 \mathrm{~Hz}\right)$, $2.27\left(\right.$ dddqd, $\left.\mathrm{H}^{5 \mathrm{a}},{ }^{2} J=17.6, J_{5 \mathrm{a}, 6 \mathrm{a}}=11.2, J_{5 \mathrm{a}, 4}=J_{5 \mathrm{a}, 10}=2.5, J_{5 \mathrm{a}, 2 \mathrm{e}}=1.4 \mathrm{~Hz}\right), 2.35$ (br. d, $\mathrm{C}^{2}-\mathrm{OH}$, $\left.J_{\mathrm{OH}, 2 \mathrm{e}} \approx 5.0 \mathrm{~Hz}\right), 2.47$ (br. dd, $\left.\mathrm{H}^{6 \mathrm{a}}, J_{6 \mathrm{a}, 5 \mathrm{a}}=11.2, J_{6 \mathrm{a}, 5 \mathrm{e}}=5.3 \mathrm{~Hz}\right), 3.80-3.84\left(\mathrm{~m}, \mathrm{H}^{2 \mathrm{e}}\right), 4.72\left(\mathrm{~m}, \mathrm{H}^{8}\right.$, all $J<2.0 \mathrm{~Hz}), 4.83\left(\mathrm{~m}, \mathrm{H}^{8}\right.$, all $\left.J<2.0 \mathrm{~Hz}\right), 5.12\left(\mathrm{dd}, \mathrm{H}^{1 \mathrm{e}}, J_{1 \mathrm{e}, 2 \mathrm{e}}=2.8, J_{1 \mathrm{e}, 6 \mathrm{a}}=1.7 \mathrm{~Hz}\right), 5.65-5.69(\mathrm{~m}$, $\left.\mathrm{H}^{4}\right) .{ }^{13} \mathrm{C}$ NMR $\left(125 \mathrm{MHz}, \mathrm{CDCl}_{3}\right): \delta 73.50\left(\mathrm{~d}, \mathrm{C}^{1}\right), 69.79\left(\mathrm{~d}, \mathrm{C}^{2}\right), 131.26\left(\mathrm{~s}, \mathrm{C}^{3}\right), 125.61\left(\mathrm{~d}, \mathrm{C}^{4}\right)$, 
$25.35\left(\mathrm{t}, \mathrm{C}^{5}\right), 38.08\left(\mathrm{~d}, \mathrm{C}^{6}\right), 144.81\left(\mathrm{~s}, \mathrm{C}^{7}\right), 111.12\left(\mathrm{t}, \mathrm{C}^{8}\right), 22.19\left(\mathrm{q}, \mathrm{C}^{9}\right), 20.54\left(\mathrm{q}, \mathrm{C}^{10}\right), 170.70(\mathrm{~s}$, $\left.\mathrm{C}^{11}\right), 20.88$ (q, $\left.\mathrm{C}^{12}\right)$. HR-MS: $193.1223\left(M^{+}-\mathrm{OH}, \mathrm{C}_{12} \mathrm{H}_{17} \mathrm{O}_{2}\right.$; calc. 193.1223).

3.3.2. Interaction of diacetate 13 with iodine. Iodine $(247.8 \mathrm{mg}, 0.976 \mathrm{mmol})$ was grinded in a mortar and dissolved in EtOAc $(3 \mathrm{ml})$. Acetic acid $(0.50 \mathrm{ml})$ and water $(1.5 \mathrm{ml})$ were added. Then a solution of $(1 R, 2 R, 6 S)$-3-methyl-6-(prop-1-en-2-yl)cyclohex-3-ene-1,2-diyl diacetate (13, 248.7 $\mathrm{mg}, 0.986 \mathrm{mmol}$ ) in $5 \mathrm{ml} \mathrm{EtOAc}$ was added. The reaction mixture was stirred for 5 days at r.t. Then it was washed with saturated solutions of $\mathrm{NaHCO}_{3}\left(2 \times 10 \mathrm{ml}\right.$, add slowly) and $\mathrm{Na}_{2} \mathrm{~S}_{2} \mathrm{O}_{3}(3 \mathrm{ml})$. The organic phase was desiccated over $\mathrm{Na}_{2} \mathrm{SO}_{4}$. The desiccant was filtered off, the solvent was evaporated. The residue (320.9 mg) was separated by CC on silica gel (9 g) using 0-100\% EtOAc gradient in hexane as eluent. This procedure gave starting diacetate $\mathbf{1 3}$ (77.4 mg, $0.307 \mathrm{mmol}$, conv. 69\%), (1R,2R,6R)-6-((S)-2-hydroxy-1-iodopropan-2-yl)-3-methylcyclohex-3-ene-1,2-diyl diacetate (14, $108.7 \mathrm{mg}$, summary formed $116.0 \mathrm{mg}, 0.293 \mathrm{mmol}, 43 \%$ calculated on reacted diacetate 13), mixture of $(1 R, 2 R, 6 R)-6-((R)-2$-hydroxy-1-iodopropan-2-yl)-3-methylcyclohex-3-ene-1,2-diol (14) and epimeric compound $\mathbf{1 5}(24.1 \mathrm{mg}, \mathbf{1 5}: \mathbf{1 3}=2.3: 1$, the content of $\mathbf{1 5}$ was $16.8 \mathrm{mg}, 0.0424 \mathrm{mmol}$, $6 \%$ calculated on reacted diol 1), (1R,2R,6S)-2-hydroxy-3-methyl-6-(prop-1-en-2-yl)cyclohex-3enyl acetate $(\mathbf{1 2}, 16.0 \mathrm{mg}, 0.0761 \mathrm{mmol}, 11 \%)$ and $(1 R, 5 S, 6 R)-6$-hydroxy-2-methyl-5-(prop-1-en-2yl)cyclohex-2-enyl acetate (11,3.3 $\mathrm{mg}, 0.0157 \mathrm{mmol}, 2 \%)$.

Compound 14. ${ }^{1} \mathrm{H}$ NMR (500 MHz, $\left.\mathrm{CDCl}_{3}\right): \delta 1.27\left(\mathrm{~s}, \mathrm{C}^{9} \mathrm{H}_{3}\right), 1.65\left(\mathrm{~m}, \mathrm{C}^{10} \mathrm{H}_{3}\right.$, all $\mathrm{J} \leq 2.5$ $\mathrm{Hz}), 1.93$ (br. s, $\left.\mathrm{C}^{7}-\mathrm{OH}\right), 2.00\left(\mathrm{~s}, \mathrm{C}^{12} \mathrm{H}_{3}\right), 2.08\left(\mathrm{~s}, \mathrm{C}^{14} \mathrm{H}_{3}\right), 2.15-2.28\left(\mathrm{~m}, 2 \mathrm{H}^{5}, \mathrm{H}^{6 \mathrm{a}}\right), 3.36\left(\mathrm{~d}, \mathrm{H}^{8},{ }^{2} \mathrm{~J}=\right.$ $10.5 \mathrm{~Hz}), 3.46\left(\mathrm{~d}, \mathrm{H}^{8^{\prime}},{ }^{2} J=10.5 \mathrm{~Hz}\right), 4.96\left(\right.$ br. d, $\left.\mathrm{H}^{2 \mathrm{e}}, J_{2 \mathrm{e}, 1 \mathrm{e}}=2.7 \mathrm{~Hz}\right), 5.17\left(\mathrm{dd}, \mathrm{H}^{1 \mathrm{e}}, J_{1 \mathrm{e}, 2 \mathrm{e}}=2.7, J_{1 \mathrm{e}, 6 \mathrm{a}}\right.$ $=1.0 \mathrm{~Hz}), 5.79-5.82\left(\mathrm{~m}, \mathrm{H}^{4}\right) .{ }^{13} \mathrm{C} \mathrm{NMR}\left(125 \mathrm{MHz}, \mathrm{CDCl}_{3}\right): \delta 68.61\left(\mathrm{~d}, \mathrm{C}^{1}\right), 70.50\left(\mathrm{~d}, \mathrm{C}^{2}\right), 128.20$ $\left(\mathrm{s}, \mathrm{C}^{3}\right), 127.82\left(\mathrm{~d}, \mathrm{C}^{4}\right), 21.69\left(\mathrm{t}, \mathrm{C}^{5}\right), 40.48\left(\mathrm{~d}, \mathrm{C}^{6}\right), 70.94\left(\mathrm{~s}, \mathrm{C}^{7}\right), 21.82\left(\mathrm{t}, \mathrm{C}^{8}\right), 23.53\left(\mathrm{q}, \mathrm{C}^{9}\right), 20.35$ $\left(\mathrm{q}, \mathrm{C}^{10}\right), 169.89\left(\mathrm{~s}, \mathrm{C}^{11}\right), 21.01\left(\mathrm{q}, \mathrm{C}^{12}\right), 169.73\left(\mathrm{~s}, \mathrm{C}^{13}\right), 20.90\left(\mathrm{q}, \mathrm{C}^{14}\right)$. HR-MS: $336.2016\left(M^{+}\right.$, $\mathrm{C}_{14} \mathrm{H}_{21} \mathrm{O}_{5} \mathrm{I}$; calc. 336.2017). 
Compound 15. The NMR spectra of compound 15 were recorded for the mixture of isomers 15 and 14 in a ratio $2.3: 1$. Data for 15: ${ }^{1} \mathrm{H}$ NMR $\left(500 \mathrm{MHz}, \mathrm{CDCl}_{3}\right): \delta 1.30\left(\mathrm{~s}, \mathrm{C}^{9} \mathrm{H}_{3}\right), 1.65-1.69$ $\left(\mathrm{m}, \mathrm{C}^{10} \mathrm{H}_{3}\right.$, all J $\left.\leq 2.5 \mathrm{~Hz}\right), 2.02\left(\mathrm{~s}, \mathrm{C}^{12} \mathrm{H}_{3}\right), 2.09\left(\mathrm{~s}, \mathrm{C}^{14} \mathrm{H}_{3}\right), 2.07-2.14\left(\mathrm{~m}, \mathrm{H}^{5 \mathrm{e}}\right), 2.18-2.23\left(\mathrm{~m}, \mathrm{H}^{5 \mathrm{a}}\right)$, $2.27\left(\mathrm{ddd}, \mathrm{H}^{6 \mathrm{a}}, J_{6 \mathrm{a}, 5 \mathrm{a}}=11.6, J_{6 \mathrm{a}, 5 \mathrm{e}}=4.7, J_{6 \mathrm{a}, 1 \mathrm{e}}=1.2 \mathrm{~Hz}\right), 3.35\left(\mathrm{~d}, \mathrm{H}^{8},{ }^{2} J=10.3 \mathrm{~Hz}\right), 3.38\left(\mathrm{~d}, \mathrm{H}^{8},{ }^{2} J=\right.$ $10.3 \mathrm{~Hz}$ ), 5.05 (br. d, $\left.\mathrm{H}^{2 \mathrm{e}}, J_{2 \mathrm{e}, 1 \mathrm{e}}=2.7 \mathrm{~Hz}\right), 5.30\left(\mathrm{ddd}, \mathrm{H}^{1 \mathrm{e}}, J_{1 \mathrm{e}, 2 \mathrm{e}}=2.7, J_{1 \mathrm{e}, 6 \mathrm{a}}=1.2, J_{1 \mathrm{e}, 5 \mathrm{e}}=0.7 \mathrm{~Hz}\right)$, $5.78-5.81\left(\mathrm{~m}, \mathrm{H}^{4}\right) .{ }^{13} \mathrm{C}$ NMR (125 MHz, $\left.\mathrm{CDCl}_{3}\right): \delta 68.76\left(\mathrm{~d}, \mathrm{C}^{1}\right), 70.22\left(\mathrm{~d}, \mathrm{C}^{2}\right), 128.48\left(\mathrm{~s}, \mathrm{C}^{3}\right)$, $127.54\left(\mathrm{~d}, \mathrm{C}^{4}\right), 22.49\left(\mathrm{t}, \mathrm{C}^{5}\right), 39.27\left(\mathrm{~d}, \mathrm{C}^{6}\right), 71.31\left(\mathrm{~s}, \mathrm{C}^{7}\right), 19.71\left(\mathrm{t}, \mathrm{C}^{8}\right), 24.85\left(\mathrm{q}, \mathrm{C}^{9}\right), 20.45\left(\mathrm{q}, \mathrm{C}^{10}\right)$, $170.18\left(\mathrm{~s}, \mathrm{C}^{11}\right), 21.15\left(\mathrm{q}, \mathrm{C}^{12}\right), 169.76\left(\mathrm{~s}, \mathrm{C}^{13}\right), 20.94\left(\mathrm{q}, \mathrm{C}^{14}\right)$.

3.3.3. Epoxide 6. A solution of $(1 R, 2 R, 6 R)-6-((R)-2-h y d r o x y-1-i o d o p r o p a n-2-y l)-3-$ methylcyclohex-3-ene-1,2-diol $(\mathbf{1 0}, 19.3 \mathrm{mg}, 0.0618 \mathrm{mmol})$ in dioxane $(5 \mathrm{ml})$ was added to water $(3$ $\mathrm{ml})$. Then $N, N$-diisopropylethylamine $(57 \mu \mathrm{L}, 0.327 \mathrm{mmol})$ was added. The reaction mixture was stirred for $24 \mathrm{~h}$, then concentrated to $1 \mathrm{ml}$ and diluted with $5 \mathrm{ml}$ saturated $\mathrm{NaCl}$. It was extracted with ethylacetate $(3 \times 3 \mathrm{ml})$. The combined organic phase was desiccated over $\mathrm{Na}_{2} \mathrm{SO}_{4}$. The desiccant was filtered off, the solvent was evaporated. The residue (15.5 $\mathrm{mg}$ ) was purified by $\mathrm{CC}$ on silica gel (2.5 g) using 0-100\% EtOAc gradient in hexane as eluent. This procedure gave $(1 R, 2 R, 6 R)-3-m e t h y l-6-((R)-2-m e t h y l o x i r a n-2-y l) c y c l o h e x-3-e n e-1,2-d i o l \quad(6, \quad 10.0 \quad \mathrm{mg}, \quad 0.0543$ mmol, $88 \%)$.

Epoxide $(R)$-6. $[\alpha]_{\mathrm{D}}{ }^{29}-74.4\left(\mathrm{c} 0.597, \mathrm{CHCl}_{3}\right) .{ }^{1} \mathrm{H} \mathrm{NMR}: \delta 1.38\left(\mathrm{~s}, \mathrm{C}^{9} \mathrm{H}_{3}\right), 1.80\left(\mathrm{~m}, \mathrm{C}^{10} \mathrm{H}_{3}\right.$, all $\mathrm{J} \leq 2.5 \mathrm{~Hz}), 2.11\left(\mathrm{ddd}, \mathrm{H}^{6 \mathrm{a}}, \mathrm{J}_{6 \mathrm{a}, 5 \mathrm{a}}=10.0 \mathrm{~Hz}, \mathrm{~J}_{6 \mathrm{a}, 5 \mathrm{e}}=6.7 \mathrm{~Hz}, \mathrm{~J}_{6 \mathrm{a}, 1 \mathrm{e}}=1.6 \mathrm{~Hz}\right), 2.16-2.21\left(\mathrm{~m}, 2 \mathrm{H}^{5}\right)$, $2.66\left(\mathrm{~d}, \mathrm{H}^{8 e x}, \mathrm{~J}_{8 e x, 8 e n}=3.9 \mathrm{~Hz}\right), 3.16\left(\right.$ br.d, $\left.\mathrm{H}^{8 e n}, \mathrm{~J}_{8 e n, 8 e x}=3.9 \mathrm{~Hz}\right), 3.79\left(\mathrm{br} . \mathrm{d}, \mathrm{H}^{2 \mathrm{e}}, \mathrm{J}_{2 \mathrm{e}, 1 \mathrm{e}}=2.8 \mathrm{~Hz}\right)$, 3.90 (br. m, $\mathrm{H}^{1 \mathrm{e}}$, all $\left.\leq 2.8 \mathrm{~Hz}\right), 5.65-5.68\left(\mathrm{~m}, \mathrm{H}^{4}\right) .{ }^{13} \mathrm{C} \mathrm{NMR}: \delta 70.74\left(\mathrm{~d}, \mathrm{C}^{1}\right), 71.68\left(\mathrm{~d}, \mathrm{C}^{2}\right), 131.76$ $\left(\mathrm{s}, \mathrm{C}^{3}\right), 124.87\left(\mathrm{~d}, \mathrm{C}^{4}\right), 22.82\left(\mathrm{t}, \mathrm{C}^{5}\right), 34.98\left(\mathrm{~d}, \mathrm{C}^{6}\right), 60.05\left(\mathrm{~s}, \mathrm{C}^{7}\right), 52.46\left(\mathrm{t}, \mathrm{C}^{8}\right), 20.87\left(\mathrm{q}, \mathrm{C}^{9}\right), 20.80$ (q, $\left.\mathrm{C}^{10}\right) . \mathrm{HR}-\mathrm{MS}: 166.0982\left(M^{+}-\mathrm{C}_{2} \mathrm{H}_{2} \mathrm{O}, \mathrm{C}_{10} \mathrm{H}_{14} \mathrm{O}_{2}\right.$; calc. 166.0988). 
3.3.4. Epoxide 7. A solution of $(1 R, 2 R, 6 R)-6-((S)-2$-hydroxy-1-iodopropan-2-yl)-3methylcyclohex-3-ene-1,2-diyl diacetate $(\mathbf{1 4}, 108.3 \mathrm{mg}, 0.273 \mathrm{mmol})$ in dioxane $(10 \mathrm{ml})$ was added to water $(6 \mathrm{ml})$. Then $N, N$-diisopropylethylamine $(0.200 \mathrm{ml}, 1.148 \mathrm{mmol})$ was added. The reaction mixture was stirred for $24 \mathrm{~h}$, then $\mathrm{NaOH}(51.3 \mathrm{mg}, 1.128 \mathrm{mmol})$ was added. The mixture was stirred $16 \mathrm{~h}$ more, then concentrated to $1 \mathrm{ml}$ and diluted with $5 \mathrm{ml}$ saturated $\mathrm{NaCl}$. It was extracted with ethylacetate $(6 \times 3 \mathrm{ml})$. The combined organic phase was desiccated over $\mathrm{Na}_{2} \mathrm{SO}_{4}$. The desiccant was filtered off, the solvent was evaporated. The residue $(57.1 \mathrm{mg})$ was purified by $\mathrm{CC}$ on silica gel (4.5 g) using 0-100\% EtOAc gradient in hexane as eluent. This procedure gave $(1 R, 2 R, 6 R)-3$ methyl-6-((S)-2-methyloxiran-2-yl)cyclohex-3-ene-1,2-diol (7, $42.4 \mathrm{mg}, 0.230 \mathrm{mmol}, 84 \%)$.

Epoxide $(S)$-7. $[\alpha]_{\mathrm{D}}{ }^{26}-76.6\left(\mathrm{c} 0.950, \mathrm{CHCl}_{3}\right) .{ }^{1} \mathrm{H} \mathrm{NMR}: \delta 1.42\left(\mathrm{~d}, \mathrm{C}^{9} \mathrm{H}_{3}, \mathrm{~J}_{9,8 e n}=0.6 \mathrm{~Hz}\right), 1.79$ $\left(\mathrm{m}, \mathrm{C}^{10} \mathrm{H}_{3}\right.$, all $\left.\mathrm{J} \leq 2.5 \mathrm{~Hz}\right), 1.87\left(\mathrm{dddq}, \mathrm{H}^{5 \mathrm{e}}, \mathrm{J}_{5 \mathrm{e}, 5 \mathrm{a}}=16.8 \mathrm{~Hz}, \mathrm{~J}_{5 \mathrm{e}, 4}=\mathrm{J}_{5 \mathrm{e}, 6 \mathrm{a}}=5.2 \mathrm{~Hz}, \mathrm{~J}_{5 \mathrm{e}, 10-\mathrm{Me}}=1.6 \mathrm{~Hz}\right)$, 1.92 (br.s, OH-C $\left.{ }^{2}\right), 1.96\left(\mathrm{ddm}, \mathrm{H}^{5 \mathrm{a}}, \mathrm{J}_{5 \mathrm{a}, 5 \mathrm{e}}=16.8 \mathrm{~Hz}, \mathrm{~J}_{5 \mathrm{a}, 6 \mathrm{a}}=11.1 \mathrm{~Hz}\right), 2.01\left(\mathrm{ddd}, \mathrm{H}^{6 \mathrm{a}}, \mathrm{J}_{6 \mathrm{a}, 5 \mathrm{a}}=11.1 \mathrm{~Hz}\right.$, $\left.\mathrm{J}_{6 \mathrm{a}, 5 \mathrm{e}}=5.2 \mathrm{~Hz}, \mathrm{~J}_{6 \mathrm{a}, 1 \mathrm{e}}=1.6 \mathrm{~Hz}\right), 2.47\left(\mathrm{br} . \mathrm{d}, \mathrm{OH}-\mathrm{C}^{1}, \mathrm{~J}_{\mathrm{OH}, 1 \mathrm{e}}=3.4 \mathrm{~Hz}\right), 2.51\left(\mathrm{~d}, \mathrm{H}^{8 e x}, \mathrm{~J}_{8 e x, 8 e n}=4.4 \mathrm{~Hz}\right)$, $2.81\left(\mathrm{dq}, \mathrm{H}^{8 e n}, \mathrm{~J}_{8 e n, 8 e x}=4.4 \mathrm{~Hz}, \mathrm{~J}_{8 e n, 9-\mathrm{Me}}=0.6 \mathrm{~Hz}\right), 3.81\left(\mathrm{br} . \mathrm{s}, \mathrm{H}^{2 \mathrm{e}}\right), 4.17\left(\mathrm{ddd}, \mathrm{H}^{1 \mathrm{e}}, \mathrm{J}_{1 \mathrm{e}, \mathrm{OH}}=3.4 \mathrm{~Hz}\right.$, $\left.\mathrm{J}_{1 \mathrm{e}, 2 \mathrm{e}}=2.8 \mathrm{~Hz}, \mathrm{~J}_{1 \mathrm{e}, 6 \mathrm{a}}=1.6 \mathrm{~Hz}\right), 5.59\left(\mathrm{ddq}, \mathrm{H}^{4}, \mathrm{~J}_{4,5 \mathrm{e}}=5.2 \mathrm{~Hz}, \mathrm{~J}_{4,5 \mathrm{a}}=2.2 \mathrm{~Hz}, \mathrm{~J}_{4,10}=1.5 \mathrm{~Hz}\right) .{ }^{13} \mathrm{C} \mathrm{NMR:}$ $\delta 71.16\left(\mathrm{~d}, \mathrm{C}^{1}\right), 71.85\left(\mathrm{~d}, \mathrm{C}^{2}\right), 131.85\left(\mathrm{~s}, \mathrm{C}^{3}\right), 124.49\left(\mathrm{~d}, \mathrm{C}^{4}\right), 22.24\left(\mathrm{t}, \mathrm{C}^{5}\right), 35.88\left(\mathrm{~d}, \mathrm{C}^{6}\right), 58.92(\mathrm{~s}$, $\left.\mathrm{C}^{7}\right), 51.30\left(\mathrm{t}, \mathrm{C}^{8}\right), 21.19$ (q, $\left.\mathrm{C}^{9}\right), 20.82$ (q, $\left.\mathrm{C}^{10}\right)$. HR-MS: $166.0986\left(M^{+}-\mathrm{C}_{2} \mathrm{H}_{2} \mathrm{O}, \mathrm{C}_{10} \mathrm{H}_{14} \mathrm{O}_{2}\right.$; calc. $166.0988)$.

3.5. Animals. The experiments were performed on C57BL/6 mice (male) weighing 25-30 g and Wistar rats (male) weighing 200-220 g purcahsed from SPF-vivarium of the Institute of Cytology and Genetics of the Siberian Branch of the Russian Academy of Sciences. The animals were maintained at $22-25^{\circ} \mathrm{C}$ on a $12 \mathrm{~h}$ light-dark cycle with food and water available ad libitum. All work with animals was guided by $3 \mathrm{R}$ principles and performed in strict accordance with the legislation of 
the Russian Federation, the regulations of the European Convention for the Protection of Vertebrate Animals Used for Experimental and Other Scientific Purposes, and the requirements and recommendations of the Guide for the Care and Use of Laboratory Animals. The use of experimental animals for isolation of primary cell cultures was approved by the Committee for Animal Experiments of the University of Helsinki (License number: KEK15-022) and these animals were treated according European guidelines and regulations of the State of Finland.

\subsection{The MPTP mouse model of Parkinson's disease induced by the fourfold administration of the MPTP neurotoxin.}

MPTP was injected intraperitoneally to mice of C57Bl/6 line every $2 \mathrm{~h}$ in $8 \mathrm{~h}$ period in one day in a dose of $0.12 \mathrm{mmol} / \mathrm{kg}(20 \mathrm{mg} / \mathrm{kg})$ for a total of four doses. The studied agent or saline was administrated per os $24 \mathrm{~h}$ after the last injection of MPTP in a dose of $0.12 \mathrm{mmol} / \mathrm{kg}(20 \mathrm{mg} / \mathrm{kg})$. The effectiveness of the studied medications was evaluated according to their ability to reduce the symptoms of hypokinesia induced by MPTP, $2 \mathrm{~h}$ after the administration of the agents. Hypokinesia caused by neurotoxin administration was evaluated with the "Open field" test performed for 2 min using Tru Scan (USA) $2 \mathrm{~h}$ after the administration of the studied agent, registering the main markers of the locomotor activity: movement distance $(\mathrm{cm})$ and duration of locomotor activity $(\mathrm{s})$. The data were analyzed using ANOVA with Dunnett's posthoc test in GraphPad Prism 6.0 software

\subsection{Influence of compound 4 on naïve mice}

The studied agent in a dose of $0.12 \mathrm{mmol} / \mathrm{kg}(20 \mathrm{mg} / \mathrm{kg})$ or saline was administrated per os to 8 mice of $\mathrm{C} 57 \mathrm{Bl} / 6$ line. The main markers of the locomotor activity (movement distance $(\mathrm{cm})$ and duration of locomotor activity (s)) were registered with the "Open field" test performed for 2 min using Tru Scan (USA), $2 \mathrm{~h}$ after the administration of the studied agent. 


\subsection{Determination of diol 1 and epoxides 4 , 7 in plasma and brain}

To identify possible metabolites, diol 1 was administred p.o. to Wistar rat in $1200 \mathrm{mg} / \mathrm{kg}$ dose. Blood sample was collected over $1 \mathrm{~h}$ period post administration. Plasma was isolated and, after protein precipitation with methanol and extraction with ethylacetate, was analyzed using GC/MS. Compound $1(695 \mu \mathrm{g} / \mathrm{mL})$ and epoxide $4(3.2 \mu \mathrm{g} / \mathrm{mL})$ were identified.

To determine the the ability of epoxide $\mathbf{4}$ to penetrate blood brain barrier, it was administred p.o. to Wistar rats $(10 \mathrm{mg} / \mathrm{kg})$. Blood samples were collected over a $1.5 \mathrm{~h}$ period post administration. Plasma was isolated and the concentration of compounds in plasma was determined by GC/MS after protein precipitation with methanol followed by extraction with ethylacetate. Brain was homogenized in $40 \%$ ethanol, filtred and then treated as it was for plasma. Ethylacetate extracts were analyzed using GC/MS. Compound 4 was found both in plasma $(5.3 \mu \mathrm{g} / \mathrm{mL})$ and in brain $(3.5$ $\mu \mathrm{g} / \mathrm{g})$.

\subsection{Preparation of the cultures of primary dopamine neurons.}

Cultures of primary dopamine (DA) neurons were prepared from E13.5 embryos of NMR1 mice. ${ }^{49}$ The embryonic midbrain floors were dissected in Dulbecco's media $\left(0.1 \mathrm{~g} / \mathrm{l} \mathrm{MgCl}_{2} \cdot 6 \mathrm{H}_{2} \mathrm{O}\right.$, $\left.0.1 \mathrm{~g} / \mathrm{l} \mathrm{CaCl} 2,8 \mathrm{~g} / 1 \mathrm{NaCl}, 0.2 \mathrm{~g} / 1 \mathrm{KCl}, 1.4 \mathrm{~g} / 1 \mathrm{Na}_{2} \mathrm{HPO}_{4} .2 \mathrm{H}_{2} \mathrm{O}, 0.2 \mathrm{~g} / 1 \mathrm{KH}_{2} \mathrm{PO}_{4}\right)$ containing $2 \%$ BSA under dissection microscope (Olympus SZX10 Stereo Microscope), washed three times with Calcium and Magnesium-free Hank's Balanced Salt Solution (HBSS: Gibco, Life Technologies) and incubated in $5 \mathrm{mg} / \mathrm{ml}$ trypsin solution in HBSS for 20 minutes at $37^{\circ} \mathrm{C}$. Enzymatic activity of trypsin was blocked by $50 \%$ Fetal Bovine Serum. To reduce the viscosity, the solution was also treated with DNase I $(10 \mathrm{mg} / \mathrm{ml})$. Cells were dissociated by trituration with siliconized glass Pasteur pipette and washed 3 times with cell culture media [(Dulbecco's MEM/Nut mix F12 
(Invitrogen/Gibco 21331-020), 1xN 2 serum supplement (Invitrogen/ Gibco 17502-048), 33 mM DGlucose (Sigma G-8769), $0.5 \mathrm{mM}$ L-Glutamine (Invitrogen/Gibco 25030-032), and $100 \mu \mathrm{g} / \mathrm{ml}$ Primocin (InvivoGen)]. Resulting pellets were resuspended in culture media and the number of alive cells (detected by trypan-blue staining) was counted using TC20 automated cell counter (BIORAD). About 30,000 cells were plated per well of 96-well Costar plate coated with Poly-L-ornithine $\left(0.5 \mathrm{mg} / \mathrm{ml}\right.$ in $0.15 \mathrm{M}$ borate buffer $\mathrm{pH} 8.7$, overnight at $\left.4^{\circ} \mathrm{C}\right)$. Different concentrations of compound $4(0.01,0.1,1,10 \mathrm{uM})$ and GDNF (Icosagen, $10 \mathrm{ng} / \mathrm{ml})$ were dissolved in culture media containing 1\% Dimethyl Sulfoxide (DMSO) and applied to the wells (in triplicates) within 1 hour post-plating. The cells were incubated for 5 days in cell culture incubator at $37^{\circ} \mathrm{C}$. Half of the cell culture media was replaced with fresh portion 2.5 days post-plating.

To evaluate neuroprotective properties of epoxide $\mathbf{4}$ in the presence of dopamine neuron toxin (6-OHDA), dopamine neurons were cultured for 5 days in cell incubator at $37^{\circ} \mathrm{C}$ and treated with 6-OHDA $(10 \mu \mathrm{M})$ along with compound $4(0.1 \mu \mathrm{M}$ and $1 \mu \mathrm{M})$ for another 3 days. GDNF (50 $\mathrm{ng} / \mathrm{ml}$ ) was used as a positive control. In these experiments we plated 40,000 cells per well to ensure that the sufficient number of cells survive until 8 DIV and the number of dopamine neurons after the toxin treatment is high enough for reliable statistical analysis. Important to note that the increase in plating cell density in our assay set-up significantly diminishes spontaneous death of THpositive neurons in culture and, therefore, the number of DA neurons in vehicle-treated wells in these experiments was higher compared to baseline values in the experiments with the survival of näive dopamine neurons.

\subsection{Tyrosine Hydoxylase and gamma-Aminobutyric acid Immunocytochemistry}


Cells were fixed with $4 \%$ PFA for 20 minutes and washed three times with PBS followed by permeabilization with $0.2 \%$ Triton $\mathrm{X}-100$ in PBS for 15 minutes. The cells were blocked by $5 \%$ Horse serum in $0.2 \%$ Triton $\mathrm{X}-100$ in PBS for 1 hour and incubated overnight at $4^{\circ} \mathrm{C}$ with antityrosine hydroxylase (TH) antibody (1:500 in blocking solution, ${ }^{50}$ Millipore Cat\# MAB318 Lot\# RRID:AB_2201528) and anti- $\gamma$-aminobutyric acid (GABA) antibody (Catalogue number: ABN131 Chemicon/Merck., diluted 1:500 in blocking solution). Cells were washed three times with PBS and incubated with secondary antibody conjugated with Alexa Fluor 647 (diluted 1:500 in blocking solution) for 1 hour at room temperature. Unbound antibody was washed out with PBS and nuclei were stained with $0.2 \mu \mathrm{g} / \mathrm{ml}$ DAPI (4',6-diamidino-2-phenylindole) in PBS for 10 minutes at room temperature. Finally, cells were washed three times with PBS and kept in PBS until imaging.

\subsection{Imaging and Statistical Analysis}

Cells were imaged by CellInsight (Life Technologies) CX5 High Content Screening (HCS) equipment. Images were analysed using CellProfiler image analysis software (BROAD Institute). Compound was analysed in triplicates in four independent experiments. ${ }^{50}$

\subsection{Primary Mesencephalic Embryonic Fibroblasts (MEF) and analysis of cell viability by}

\section{Alamar blue assay}

Cultures of primary mesencephalic embryonic fibroblasts (MEF) were prepared from E13.5 embryos of NMR1 mice as described previously with slight modifications. ${ }^{51}$ Mouse was killed by exposure to $\mathrm{CO}_{2}$ and subsequent cervical dislocation. Embryos were dissected from uterus. Head and red organs were discarded, and remaining portions of embryos were placed in separate clean dish containing PBS. The tissues were chopped into small pieces with the help of sterile razor blade. Tissues were washed three times with Calcium and Magnesium-free Hank's Balanced Salt Solution 
(HBSS: Gibco, Life Technologies) and incubated in $5 \mathrm{mg} / \mathrm{ml}$ trypsin solution in HBSS for 20 minutes at $37^{\circ} \mathrm{C}$. About two volumes of MEF medium [DMEM (Cat N 21063-029, Gibco), 10\% FBS, $1 \%$ L-glutamine (Cat N 25030-032, Invitrogen/ Gibco), $0.2 \%$ Normacin)] was added and then the tissues were triturated three times using Pasteur pipettes. The cells were pelleted by centrifugation, resuspended in warm fresh MEF medium and plated in $10 \mathrm{~cm}$ dish. Upon reaching confluency, the cells were collected, distributed to several cryogenic vials and frozen for further experiments.

Analysis of cell viability in MEFs was carried out using method described by Nakayama and co-authors. ${ }^{52}$ For each experiment a new vial of MEFs was melted and cells were plated on 96 well (OptiPlate 96 F HB, Wallac) plate. Next day, various concentration of epoxide 4 were applied in media containing DMEM, $2 \%$ DMSO and 30 mM HEPES. After three days of culturing in presence of epoxide 4, Alamar blue dissolved in cell culture media in ratio of 1:10 was added to the cultured cells. The fluorescence was measured using FLUOstar Omega Multi-Mode Microplate Reader (BMG LABTECH) four hours post treatment with Alamar Blue. Experiments were performed in quadruplicates and repeated 3 times. The data presented in Fig. 6B are from the single experiment, but were reproduced 3 times.

\subsection{Analysis of RET, TrkB, ERK and Akt activation by compound 4.}

The level of phosphorylated RET, TrkB, Erk and Akt was evaluated using methods described previously. ${ }^{53,54}$

\subsubsection{Cell lines}

MG87RET murine fibroblasts stably transfected with RET oncogene,${ }^{55}$ MG87TrkB murine

fibroblasts were stably transfected with TrkB receptor tyrosine kinase. ${ }^{56,57}$ Neuro 2 a cells (ATCC) were used to study the intracellular signaling in response to compound 4. 
MG87RET cells were transfected with hGFR $\alpha 1$ (Full-length human GFR $\alpha 1$ cDNA subcloned in pCDNA6 (Invitrogen, USA)) $)^{58}$ using Lipofectamine 2000 (Invitrogen), as described by the manufacturer.

\subsubsection{Sample preparation}

To assess the levels of RET and TrkB phosphorylation MG87RET/GFR $\alpha 1$ or MG87TrkB cells were plated into 6-well plates in DMEM and cultured overnight in DMEM, 10\% FBS, normocin. Next day cells were starved for 4 hours in DMEM, 1\% DMSO, $15 \mathrm{mM}$ Hepes $\mathrm{pH}=7.2$, treated with compound 4 or positive control proteins GDNF and BDNF for $15 \mathrm{~min}$, washed with icecold PBS (phosphate buffered saline, $\mathrm{pH} 7.4 ; 137 \mathrm{mM} \mathrm{NaCl}, 2.7 \mathrm{mM} \mathrm{KCl}, 10 \mathrm{mM} \mathrm{PO}_{4}{ }^{3-}$ ) containing $1 \mathrm{mM} \mathrm{Na} \mathrm{VO}_{4}$ and lysed in RIPA-modified buffer (50 mM Tris-HCl, $\mathrm{pH}$ 7.4, $150 \mathrm{mM} \mathrm{NaCl}, 1 \mathrm{mM}$

EDTA, 1\% NP-40, 1\% TX-100, 10\% glycerol, EDTA-free protease inhibitor cocktail (Roche, Switzerland), $1 \mathrm{mM} \mathrm{Na} \mathrm{VO}_{4}, 6 \mathrm{mM}$ sodium deoxycholate, $1 \mathrm{mM}$ PMSF). To assess the levels phosphorylated Erk and Akt, MG87RET/GFR $\alpha 1$ or Neuro2A cells were plated into 48 -well plates, cultured and starved as described above. Then, the cells were treated with compound $\mathbf{4}$ or GDNF (MG87RET/GFR $\alpha 1$ ) and washed with ice-cold PBS containing $1 \mathrm{mM} \mathrm{Na} \mathrm{VO}_{4}$ and $1 \mathrm{mM} \mathrm{NaF}$. Cells were lysed by Laemmli loading buffer.

\subsubsection{Analysis of RET phosphorylation by Western blotting}

The level of RET phosphorylation in the cells was analyzed by Western blotting of immunoprecipitated RET with phospho-tyrosine-specific antibody (1:1500, Merck Millipore Cat\# 05-321, RRID:AB_309678) as described previously. ${ }^{58}$ Equal loading was confirmed by re-probing the membrane with anti-RET C-20 antibody (1:500, Santa Cruz Biotechnology Cat\# sc-1290, RRID:AB_631316).

\subsubsection{Western blotting-based ERK and AKT phosphorylation assay}


Levels of pERK and pAKT in immortalized cells were analyzed by Western blotting using E4 pERK (1:1000, Santa Cruz Biotechnology Cat\# sc-7383, RRID:AB_627545) and pAKT (1:500, Cell Signaling Technology Cat\# 9271, RRID:AB_329825) antibodies as described previously. ${ }^{53}$ Membranes were probed with GAPDH antibody (1:4000, Millipore Cat\# MAB374, RRID:AB_2107445) to confirm equal loading. Western blotting images of phosphorylated ERK and AKT from Neuro 2A cells were quantified using Image studio-lite (LI-COR Biosciences, UK) software. The intensity of staining of each band (normalized to area) was divided by the intensity of GAPDH band (normalized to area) for each individual lane on the gel. The data for different time points were averaged and subjected to statistical analysis using paired t-test in GraphPad Prism v6.

\subsection{Assessment of neurorestorative properties of epoxide 4 in vivo}

\subsubsection{Sample collection and Tissue Processing.}

MPTP was injected intraperitoneally to mice of C57Bl/6 line every $2 \mathrm{~h}$ an $8 \mathrm{~h}$ period in one day in a dose of $0.12 \mathrm{mmol} / \mathrm{kg}(20 \mathrm{mg} / \mathrm{kg})$ for a total of four doses. Epoxide 4 or saline were administrated per os $24 \mathrm{~h}$ after the last injection of MPTP in doses of $0.12 \mathrm{mmol} / \mathrm{kg}(20 \mathrm{mg} / \mathrm{kg})$ or $0.03 \mathrm{mmol} / \mathrm{kg}(5 \mathrm{mg} / \mathrm{kg})$. Then, epoxide 4 or saline were injected for 14 days in 5 day per week regime, for a total of fifteen doses. The samples were collected 7 days after the last administration of epoxide 4. Mice were perfused trans-cardially with PBS and then $4 \%$ paraformaldehyde in accordance with, ${ }^{59}$ the brains were collected, treated and embedded into paraffin blocks using histological complex Microm (Germany).

\subsubsection{Immunohistochemistry.}

To analyze the effect of epoxide 4 in dopamine neurons in vivo, tyrosine hydroxylase immunohistochemistry was performed as described previously. ${ }^{60}$ The PFA-fixed and paraffinembedded brains were cut into $5 \mu \mathrm{M}$ thick sections ( 3 sections per slide) and every $5^{\text {th }}$ slide was 
taken for TH staining. The sections were deparaffinized followed by citrate antigen retrieval procedure. Endogenous peroxidase was inactivated by $30 \mathrm{~min}$ incubation with $3 \% \mathrm{H}_{2} \mathrm{O}_{2}$. The sections were blocked with $5 \%$ normal goat serum and then probed with monoclonal anti-tyrosine hydroxylase (TH) antibody (1:2,000, Millipore Cat\# MAB318 Lot\# RRID:AB_2201528) overnight at $+4^{\circ} \mathrm{C}$. The sections were washed, and biotinylated horse antimouse secondary antibody $(1: 200$,

Cat\# BA-2001, Vector Laboratories, Burlingame, CA, USA) was applied for 1 hour followed by washing. The sections were treated with $\mathrm{ABC}$ and $\mathrm{DAB}$ staining kits (Vector Laboratories, CA, USA) according to manufacturer's instructions to visualize bound antibodies.

\subsection{Optical density and TH positive neurons}

The sections were scanned with an automated scanner (3DHistech, Budapest, Hungary; http://www.biocenter.helsinki.fi/bi/histoscanner/index.html), and the images were converted to 16bit gray scale. The signal from cortical staining was used to measure nonspecific background staining. The integrated optical densities in images were measured in Image J (NIH) and divided by area in pixels.

3.16. Statistical Analysis. Statistical analysis of the data was performed using one-way ANOVA with a Dunnett's posthoc test for the comparison of multiple treatment groups or paired ttest in Graphpad Prism v6 software (La Jolla, CA, USA). All data are presented as mean \pm SEM. P values below 0.05 were considered to indicate statistically significant differences between groups. No exclusions were made from the data from behavioral tests. One outlier was excluded from the vehicle-treated group in the experiments assessing the survival of dopamine neurons in response to compound 4 using Grubb's test. No other exclusion were made in any of the experiments.

Supporting information: ${ }^{1} \mathrm{H}$ and ${ }^{13} \mathrm{C}$ NMR spectra for epoxides 4-7. 


\section{Corresponding Author Information}

Konstantin P. Volcho, e-mail: volcho@ nioch.nsc.ru

\section{Author Contributions}

These authors contributed equally: Oleg V. Ardashov, Arun Kumar Mahato, Ekaterina A. Morozova, Alla V. Pavlova

\section{Acknowledgments}

Current work was financially supported by FP7-PEOPLE-2013-IAPP GA N612275, Parkinson's UK Innovation Grant K-1408 and Russian Foundation for Basic Research (Grant No 19-03-00071a). We thank Jenni Montonen and Elena Burtovskaia for their excellent assistance with experimental procedures. We thank Prof. Mart Saarma for critical comments to this paper.

\section{References}

1. de Lau, L. M.; Breteler, M. Epidemiology of Parkinson's disease. Lancet Neurol. 2006, 5 (6), $525-535$.

2. Lees, A. J.; Hardy, J.; Revesz, T. Parkinson's disease. Lancet 2009, 373 (9680), 2055-2066.

3. Kowal, S. L.; Dall, T. y M.; Chakrabarti, R.; Storm, M. V.; Jain, A. The Current and Projected Economic Burden of Parkinson's Disease in the United States. Mov Disord. 2013, $28(3), 311-318$.

4. Hennemann, J.; Schatton, W.; Lyssy, R. H. Parkinsonism Treatment. Ullmann's Encyclopedia of Industrial Chemistry 2012, 26, 207-230.

5. Dauer, W.; Przedborski, S. Parkinson's disease: mechanisms and models. Neuron 2003, 39 (6), 889-909. 
6. Whitfield, A. C.; Moore, B. T.; Daniels, R. N. Classics in Chemical Neuroscience: Levodopa. ACS Chem. Neurosci. 2014, 5 (12), 1192-1197.

7. Pedrosa, D. J.; Timmermann, L. Review: management of Parkinson's disease. Neuropsychiatric Disease and Treatment 2013, 9, 321-340.

8. Kakkar, A. K.; Dahiya, N. Management of Parkinson's disease: Current and future pharmacotherapy. Eur. J. Pharm.2015, 750, 74-81.

9. Fahn, S.; Oakes, D.; Shoulson, I.; Kieburtz, K.; Rudolph, A.; Lang, A.; Olanow, C. W.; Tanner, C.; Marek, K. Levodopa and the Progression of Parkinson's Disease. N. Engl. J. Med. 2004, 351 (24), 2498-2508.

10. Ardashov, O. V.; Pavlova, A. V.; Il'ina, I. V.; Morozova, E. A.; Korchagina, D. V.; Karpova, E. V.; Volcho, K. P.; Tolstikova, T. G.; Salakhutdinov, N. F. Highly potent activity of (1R,2R,6S)-3-methyl-6-(prop-1-en-2-yl)cyclohex-3-ene-1,2-diol in animal models of Parkinson's disease. J. Med. Chem. 2011, 54 (11), 3866-3874.

11. Valdman, E.; Kapitsa, I.; Ivanova, E.; Voronina, T.; Ardashov, O.; Volcho, K.; Khazanov, V.; Salakhutdinov, N. Evolution of anti-parkinsonian activity of monoterpenoid $(1 R, 2 R, 6 S)-3-$ methyl-6-(prop-1-en-2-yl)cyclohex-3-ene-1,2-diol in various in vivo models. Eur. J. Pharmacol. 2017, 815, 351-363.

12. Tolstikova, T. G.; Pavlova, A. V.; Morozova, Ye. A.; Ardashov, O. V.; Il'ina, I. V.; Volcho, K. P.; Salakhutdinov, N. F.; Tolstikov, G. A. A highly effective antiparkinsonian drug of a new structural type. Doklady Biological Sciences 2010, 435 (1), 398-399.

13. Ardashov, O. V.; Pavlova, A. V.; Korchagina, D. V.; Volcho, K. P.; Tolstikova, T. G.; Salakhutdinov, N. F. 3-Methyl-6-(prop-1-en-2-yl) cyclohex-3-ene-1,2-diol: the Importance of Functional Groups for Antiparkinsonian Activity. Med. Chem., 2013, 9 (5), 731-739 
14. Ardashov, O. V.; Pavlova, A. V.; Korchagina, D. V.; Volcho, K. P.; Tolstikova, T. G.; Salakhutdinov, N. F. Antiparkinsonian activity of some 9-N-, O-, S- and C-derivatives of 3methyl-6-(prop-1-en-2-yl)cyclohex-3-ene-1,2-diol. Bioor. Med. Chem. 2013, 21 (5), 10821087.

15. Ardashov, O. V.; Demidova, Yu.S.; Korchagina, D. V.; Simakova, I. L.; Volcho K. P.; Salakhutdinov, N. F. The first synthesis of (4S,5R,6R)-5,6-dihydroxy-4-(prop-1-en-2yl)cyclohex-1-enecarboxylic acid. Helv. Chim. Acta, 2015, 98 (10), 1442-1455.

16. Brown, S. M.; Davies, S. G.; de Sousa, J. A. A. Kinetic resolution strategies I: Enhanced product enantiomeric excesses and yields in Sharpless epoxidations. Tetrahedron: Asymm. 1991, 2 (7), 511-514.

17. Ardashov, O. V.; Zarubaev, V. V.; Shtro, A. A.; Korchagina, D. V.; Volcho, K. P.; Salakhutdinov, N. F.; Kiselev, O. I. Antiviral activity of 3-methyl-6-(prop-1-en-2yl)cyclohex-3-ene-1,2-diol and its derivatives against influenza A(H1N1)2009 virus. Lett. Drug Des. Discov. 2011, 8 (4), 375-380.

18. Ardashov, O. V.; Volcho, K. P.; Salakhutdinov, N. F. Synthesis of hydroxy derivatives of limonene. Russ. Chem. Rev. 2014, 83 (4), 281-298.

19. Volcho, K. P.; Salakhutdinov, N. F. Transformations of Terpenoids on Acidic Clays. Mini Rev. Org. Chem. 2008, 5 (4), 345-354.

20. McGonigle, P. Animal models of CNS disorders. Biochem. Pharmacol. 2014, 87 (1), 140149.

21. Jackson-Lewis, V.; Przeborski, S. Protocol for the MPTP mouse model of Parkinson's disease. Nature protocols 2007, 2 (1), 141. 
22. Ardashov, O. V.; Pavlova, A. V.; Korchagina, D. V.; Tolstikova, T. G.; Volcho, K. P.; Salakhutdinov, N. F. 3-Methyl-6-(prop-1-en-2-yl)cyclohex-3-en-1,2-diol-epoxides - new antiparkinsonian drugs and anti-convulsants. Patent RU 2571299, 2015.

23. Sidorova, Y. A.; Volcho, K. P.; Salakhutdinov, N. F. Neuroregeneration in Parkinson's disease: from proteins to small molecules. Current Neuropharmacology, 2019, 17 (3) 268287. .

24. Herrera-Arozamena, C.; Martí-Marí, O.; Estrada, M.; Revenga, M. F.; Rodríguez-Franco, M. I. Recent Advances in Neurogenic Small Molecules as Innovative Treatments for Neurodegenerative Diseases. Molecules 2016, 21 (9), 1165-1186.

25. Douaron, G. L.; Ferrie, L.; Sepulveda-Diaz, J. E.; Amar, M.; Harfouche, A.; Seon-Meniel, B.; Raisman-Vozari, R.; Michel, P. P.; Figadere, B. New 6-aminoquinoxaline derivatives with neuroprotective effect on dopaminergic neurons in cellular and animal Parkinson disease models. J. Med. Chem. 2016, 59 (13), 6169-6186.

26. Lin, L. F.; Doherty, D. H.; Lile, J. D.; Bektesh, S.; Collins, F. GDNF: A Glial Cell LineDerived Neurotrophic Factor for Midbrain Dopaminergic Neurons. Science 1993, 260 (5111): 1130-1132.

27. Yu, L.-Y.; Jokitalo, E.; Sun, Y.-F.; Mehlen, P.; Lindholm. D.; Saarma, M.; Arumäe, U. GDNF-deprived sympathetic neurons die by nonmitochondrial pathway. J. Cell Biol. 2003, $163(5), 987-997$.

28. Gaven, F.; Marin, P.; Claeysen, S. Primary culture of mouse dopaminergic neurons. J. Vis. Exp. 2014, 91, e51751.

29. Hyman, C.; Hofer, M.; Barde, Y.-A.; Juhasz, M.; Yancopoulos, G. D.; Squinto, S. P.; Lindsay, R. M. BDNF is a neurotrophic factor for dopaminergic neurons of the substantia nigra. Nature 1991, 350 (6315), 230-232. 
30. Treanor, J. J. S.; Goodman, L.; de Sauvage, F.; Stone, D. M.; Poulsen, K. T.; Beck, C. D.; Gray, C.; Armanini, M. P.; Pollock, R. A.; Hefti, F.; Phillips, H. S.; Goddard, A.; Moore, M. W.; Buj-Bello, A.; Davies, A. M.; Asai, N.; Takahashi, M.; Vandlen, R.; Henderson, C. E.; Rosenthal, A. Characterization of a multicomponent receptor for GDNF. Nature 1996, 382 (6586), 80-83.

31. Klein, R.; Nanduri, V.; Jing, S.; Lamballe, F.; Tapley, P.; Bryant, S.; Cordon-Cardo, C.; Jones, K. R.; Reichardt, L. F.; Barbacid, M.. The trkB tyrosine protein kinase is a receptor for brain-derived neurotrophic factor and neurotrophin-3. Cell 1991, 66 (2), 395-403.

32. Airaksinen, M. S.; Saarma, M. The GDNF family: signalling, biological functions and therapeutic value. Nat. Rev. Neurosci. 2002, 3 (5), 383-394.

33. Mizuta, I.; Ohta, M.; Ohta, K.; Nishimura, M.; Mizuta, E.; Hayashid, K.; Kuno, S. Selegiline and desmethylselegiline stimulate NGF, BDNF, and GDNF synthesis in cultured mouse astrocytes. Biochem. Biophys. Res. Commun. 2000, 279 (3), 751-755.

34.Zhao, Q.; Cai, D.; Bai, Y. Selegiline rescues gait deficits and the loss of dopaminergic neurons in a subacute MPTP mouse model of Parkinson's disease. Int. J. Mol. Med. 2013, 32 (4), 883-891.

35. Dudek, H.; Datta, S. R.; Franke, T. F.; Birnbaum, M. J.; Yao, R.; Cooper, G. M.; Segal, R. A.; Kaplan, D. R.; Greenberg, M. E. Regulation of neuronal survival by the serine-threonine protein kinase Akt. Science, 1997, 275 (5300), 661-665.

36. Malagelada, C.; Jin, Z. H.; Greene, L. A. RTP801 Is Induced in Parkinson's Disease and Mediates Neuron Death by Inhibiting Akt Phosphorylation/Activation. J. Neuroscience, 2008, 28 (53), 14363-14371.

37. Perron, J. C.; Bixby, J. L. Distinct neurite outgrowth signaling pathways converge on ERK activation. Molecular and Cellular Neurosciences 1999, 13 (5), 362-378. 
38. Parmar, M. S.; Jaumotte, J. D.; Wyrostek, S. L.; Zigmond, M. J.; Cavanaugh, J. E. The role of ERK1, 2, and 5 in dopamine neuron survival during aging. Neurobiology of Aging 2014, 35 (3), 669-679.

39. Il'ina, I. V.; Volcho, K. P.; Korchagina, D. V.; Barkhash, V. A.; Salakhutdinov, N. F. Reactions of Allyl Alcohols of the Pinane Series and of Their Epoxides in the Presence of Montmorillonite Clay. Helv. Chim. Acta 2007, 90 (2), 353-368.

40. Ardashov, O.V.; Il'ina, I.V.; Korchagina, D.V.; Volcho, K.P.; Salakhutdinov, N.F. Unusual $\alpha$-hydroxyaldehyde with a cyclopentane framework from verbenol epoxide. Mendeleev Commun. 2007, 17 (5), 303-305.

41. Imre, G.; Jákli, I.; Kalászi, A.; Farkas, Ö. Advanced Automatic Generation of 3D Molecular Structures. $1^{\text {st }}$ European Chemistry Congress, Budapest, Hungary, 27-31 August, 2006.

42. Chang, C.; Gilson, M. K. Tork: Conformational analysis method for molecules and complexes. J. Comput. Chem. 2003, 24 (16), 1987-1998.

43. Ren, P.; Ponder, J. W. Polarizable Atomic Multipole Water Model for Molecular Mechanics Simulation. J. Phys. Chem. B 2003, 107 (24), 5933-5947.

44. Laikov, D. N. Fast evaluation of density functional exchange correlation terms using the expansion of the electron density in auxiliary basis sets. Chem. Phys. Lett. 1997, 281 (1-3), 151-156.

45. Laikov, D. N.; Ustynyuk, Y. A. PRIRODA-04: a quantum-chemical program suite. New possibilities in the study of molecular systems with the application of parallel computing. Russ. Chem. Bull. 2005, 54 (3), 820-826.

46. Perdew, J. P.; Burke, K.; Ernzerhof, M. Generalized gradient approximation made simple. Phys. Rev. Lett. 1996, 77 (18), 3865-3868. 
47. Laikov, D. N. A new class of atomic basis functions for accurate electronic structure calculations of molecules. Chem. Phys. Lett. 2005, 416 (1-3), 116-120.

48. Planken, A.; Porokuokka, L. L.; Hanninen, A. L.; Tuominen, R. K.; Andressoo, J. O. Medium-Throughput Computer Aided Micro-Island Method to Assay Embryonic Dopaminergic Neuron Cultures in Vitro. J. Neurosci. Methods 2010, 194 (1): 122-131.

49. Baell, J. B.; Holloway, G. A. New substructure filters for removal of pan assay interference compounds (PAINS) from screening libraries and for their exclusion in bioassays. $J$. Med. Chem. 2010, 53 (7), 2719-2740.

50. Saarenpaa, T.; Kogan, K.; Sidorova, Y.; Mahato, A. K.; Tascon, I.; Kaljunen, H.; Yu, L.; Kallijarvi, J.; Jurvansuu, J.; Saarma, M.; Goldman, A. Zebrafish GDNF and its co-receptor GFR $\alpha 1$ activate the human RET receptor and promote the survival of dopaminergic neurons in vitro. PLoS ONE 2017, 12 (5), e0176166.

51. Jozefczuk, J.; Drews, K.; Adjaye, J. Preparation of Mouse Embryonic Fibroblast Cells Suitable for Culturing Human Embryonic and Induced Pluripotent Stem Cells. J. Vis. Exp. 2012, 64, e3854.

52. Nakayama, G. R.; Caton, M. C.; Nova, M.P.; Parandoosh, Z. Assessment of the Alamar Blue assay for cellular growth and viability in vitro. J. Immunol. Methods 1997, 204 2, 205-208.

53. Sidorova, Y. A.; Bespalov, M. M.; Wong, A. W.; Kambur, O.; Jokinen, V.; Lilius, T. O.; Suleymanova, I.; Karelson, G.; Rauhala, P. V.; Karelson, M.; Osborne, P. B.; Keast, J. R.; Kalso, E. A.; Saarma M. A Novel Small Molecule GDNF Receptor RET Agonist , BT13 , Promotes Neurite Growth from Sensory Neurons in Vitro and Attenuates Experimental Neuropathy in the Rat. Front. Pharmacol. 2017, 8, 1-18. 
54. Sidorova, Y. A.; Mätlik, K.; Paveliev, M.; Lindahl, M.; Piranen, E.; Milbrandt, J.; Arumäe, U.; Saarma, M.; Bespalov M. M. Persephin signaling through GFRalpha1: the potential for the treatment of Parkinson's disease. Mol. Cell Neurosci. 2010, 44 (3), 223-232.

55. Eketjäll, S.; Fainzilber, M.; Murray-Rust, J.; Ibáñez C. F. Distinct structural elements in GDNF mediate binding to GFR $\alpha 1$ and activation of the GFR $\alpha 1-c-$ Ret receptor complex. EMBO J. 1999, 18 (21), 5901-5910.

56. Glass, D. J.; Nye, S. H.; Hantzopoulos, P.; Macchi, M. J.; Squinto, S. P.; Goldfarb, M.; Yancopoulos, G. D. TrkB mediates BDNF/NT-3-dependent survival and proliferation in fibroblasts lacking the low affinity NGF receptor. Cell 1991, 66, 405-413.

57. Ip, N. Y.; Stitt, T. N.; Tapley, P.; Klein, R.; Glass, D. J.; Fandl, J.; Greene, L. A.; Barbacid, M.; Yancopoulos, G. D. Similarities and differences in the way neurotrophins interact with the Trk receptors in neuronal and nonneuronal cells. Neuron 1993, 10, 137-149.

58. Leppänen, V.-M.; Bespalov, M. M.; Runeberg-Roos, P.; Puurand, Ü.; Merits A.; Saarma, M.; Goldman A. The structure of GFRalphal domain 3 reveals new insights into GDNF binding and RET activation. EMBO J. 2004, 23 (7), 1452-1462.

59. Gage, G. J.; Kipke, D. R.; Shain, W. Whole animal perfusion fixation for rodents. J. Vis. Exp. 2012, 65, e3564.

60. Penttinen, A. M.; Suleymanova, I.; Albert, K.; Anttila, J.; Voutilainen, M. H.; Airavaara, M. Characterization of a new low-dose 6-hydroxydopamine model of Parkinson's disease in rat. J. Neurosci. Res. 2016, 94 (4), 318-328.

\section{For Table of Contents Only}




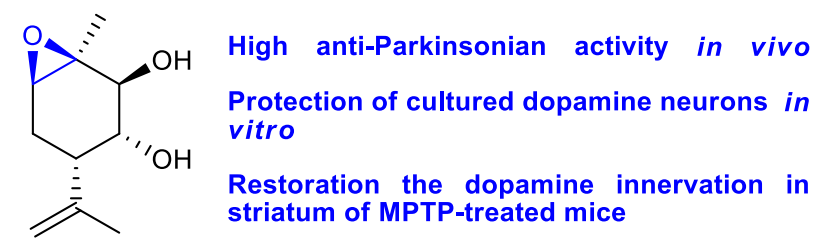

